\title{
Post-Crisis Recovery: When Does Increased Fiscal Discipline Work?
}

\author{
Pritha Mitra
}





\title{
IMF Working Paper
}

IMF Institute

\section{Post-Crisis Recovery: When Does Increased Fiscal Discipline Work?}

\author{
Prepared by Pritha Mitra
}

Authorized for distribution by Roland Daumont ${ }^{1}$

September 2006

\begin{abstract}

\section{This Working Paper should not be reported as representing the views of the IMF.}

The views expressed in this Working Paper are those of the author(s) and do not necessarily represent those of the IMF or IMF policy. Working Papers describe research in progress by the author(s) and are published to elicit comments and to further debate.

Emerging market financial crises during the late 1990s were marked by sudden withdrawals of funds by foreign creditors, resulting in production declines. The IMF favored positive signals to potential foreign creditors and initially recommended disciplined fiscal policy during the height of crisis, countering standard Keynesian recommendations of expansionary fiscal stimulus. This paper formulates an open-economy general equilibrium model for resolving this policy conundrum and analyzing the impact of disciplined fiscal policy on post-crisis recovery. The model demonstrates via simulations that disciplined fiscal policy will improve (worsen) post-crisis recovery in the presence (absence) of appropriately defined production flexibility

JEL Classification Numbers: E10, E30, E62, F41, F47

Keywords: Financial crisis, Emerging markets, Fiscal policy

Author(s) E-Mail Address: pmitra@imf.org

\footnotetext{
${ }^{1}$ The author is indebted to Padma Desai for insightful advice. The author is also grateful for helpful suggestions from Jean Boivin, Mitali Das, Roland Daumont, Andrew Feltenstein, James Gordon, David Jestaz, Eric LeBorgne, Alexei Onatski, Bruce Preston, Filippo Taddei, Xavier Sala-i-Martin, Josep Vilarrubia, and Sujata Visaria. Thanks to seminar participants at Columbia University and the International Monetary Fund for invaluable comments. All the usual caveats apply.
} 


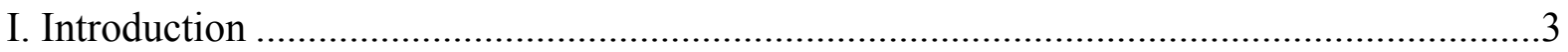

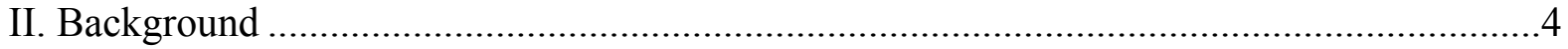

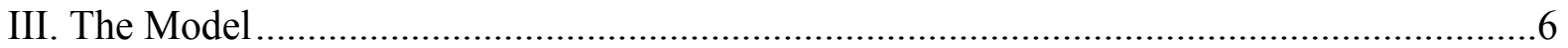

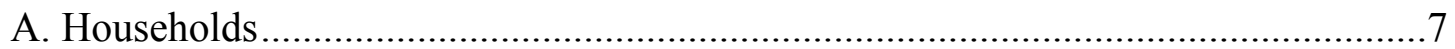

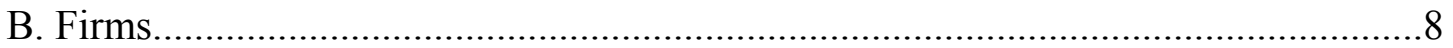

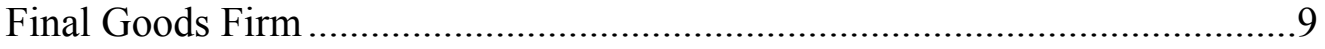

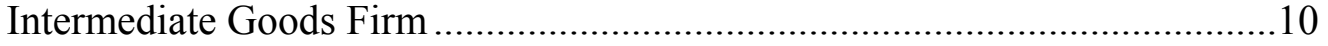

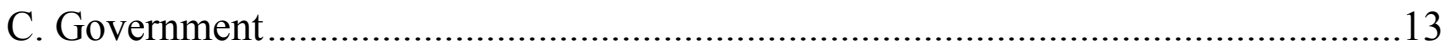

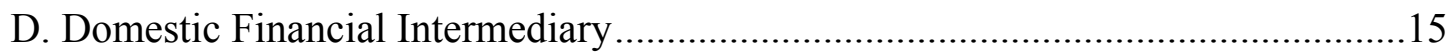

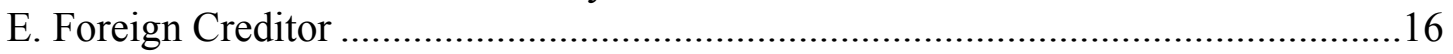

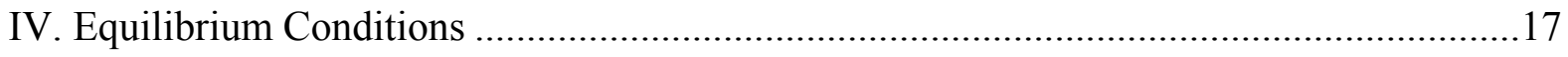

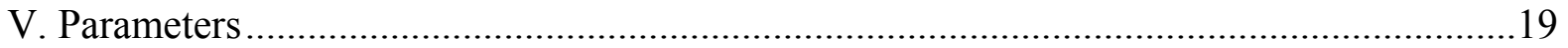

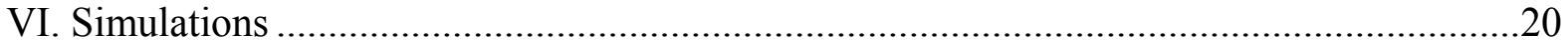

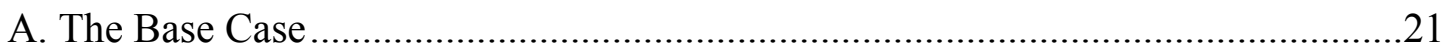

Government in the Base Case .................................................................22

Firms in the Base Case.............................................................................24

Foreign Creditor in the Base Case ...........................................................26

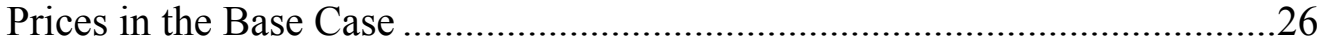

B. Application of Disciplined Fiscal Policy ...........................................................28

Flexibility in Production of Tradable Goods under Disciplined

Fiscal Policy ........................................................................................28

Less Flexibility in Production of Tradable Goods under Disciplined

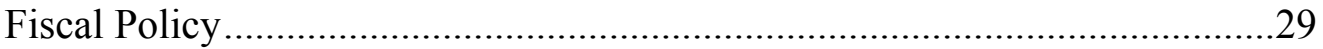

C. Application of Simulation Results to Korea and Thailand ................................... 31

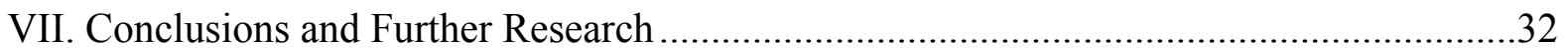

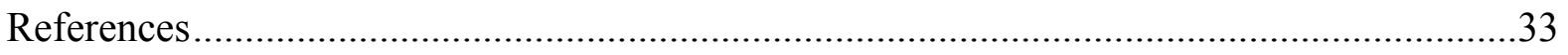

Figures

1-8. Post-Crisis Paths, under 3\% Budget Surplus Target.....................................................23

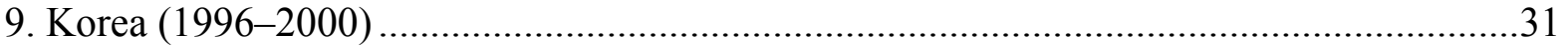

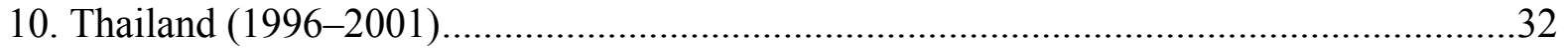

Table

1. Parameter Values for Model Calibration .......................................................................20

Appendix Figures

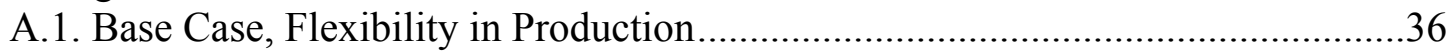

A.2. Three Percent Budget Surplus, Flexibility in Production ....................................38

A.3. Base Case, Less Flexibility in Production ......................................................40

A.4. Three Percent Budget Surplus, Less Flexibility in Production ............................42 


\section{INTRODUCTION}

Several emerging market economies experienced financial crisis in the late 1990s as a result of the sudden withdrawal of short-term funds by foreign creditors. Standard Keynesian policies prescribe expansionary fiscal stimulus for initiating the recovery process. In contrast, the IMF recommended disciplined fiscal policy (for example, reducing the deficit as a percentage of GDP through expenditure reduction or revenue-increasing measures) to emerging markets during the height of crisis. ${ }^{2}$ How valid is this recommendation disciplined fiscal policy?

Recent financial crises in East Asia (1997), Russia (1998), Turkey (2000), and Argentina (2001) primarily originated from a combination of stable (or fixed) exchange rates, free capital mobility, and emerging market interest rates that were higher than world levels. ${ }^{3}$ Emerging market borrowers borrowed short-term from abroad in foreign currencies and lent long-term at home creating assets that were recoverable in domestic currencies. As a result of the double mismatch, these borrowers found it difficult to repay their foreign-currencydenominated debts when an exogenous shock against their currencies pulled them down. ${ }^{4}$ Speculation against the currencies intensified the nonpayment process. Excessive borrowing by some governments resulted in sovereign debt defaults, whereas heavy borrowing by the private sector created widespread bankruptcies, business closures, declining outputs, and employment.

I investigate the effects of disciplined fiscal policy during recovery from this type of financial crisis in the framework of a standard open-economy general equilibrium model. My model demonstrates that disciplined fiscal policy positively stimulates the recovery process of an economy with specific structural characteristics. In contrast, disciplined fiscal policy worsens the recession in an economy that lacks such adaptive features. I show that the results of my

\footnotetext{
${ }^{2}$ The IMF's initial fiscal policy recommendations, not based on any anti-Keynesian views, were justified on the grounds that these measures served as a signaling device during crisis, indicating the resolve of the crisis-ridden economy's government to take corrective action. In particular, the recommendations were aiming to inspire confidence in foreign creditors and initialize the return of foreign capital inflows. However, when the severity of the output collapse became evident, the extent of fiscal tightening was relaxed, allowing increased government spending while maintaining fiscal discipline. See p.32, Chapter 4 of IMF Evaluation Report (2003) for details. Nonetheless, the IMF recommendations of disciplined fiscal policy have been criticized vigorously. Furman and Stiglitz (1998), and Sachs (1998) advocated standard Keynesian expansionary fiscal policies for crisis-ridden economies arguing that IMF fiscal tightening would aggravate the crisis.

${ }^{3}$ The complete list of factors contributing to financial crisis is extensive. The first paragraph in the Background section of this paper provides several noteworthy references relating to the origins of financial crisis.

${ }^{4}$ The exogenous factor that hit the Thai baht in 1997 was the U.S. dollar appreciating against the Japanese yen, in turn affecting the competitive position of the Asian currencies (vis-à-vis the yen), pegged to the dollar. Details are in Desai (2003a).
} 
model match the observed recovery patterns of emerging market economies.

My policy conclusion is that disciplined fiscal policy should neither be blindly dismissed nor blithely applied in crisis-ridden or recession-prone emerging market economies. An assessment of the private sector's production flexibility, defined as the ability to substitute domestic inputs for imported inputs, combined with an assessment of the interactive fiscal link between the private sector and the government, will determine the success or failure of fiscal policy. ${ }^{5}$

The remainder of the paper includes six sections. Section II briefly discusses some of the literature in this area and provides a general description of the model. The details of the model and its solution are described in Sections III and IV. Proceeding from these theoretical foundations, the model parameters are quantified in Section V. Section VI explores the impact of fiscal policy through model simulations. Section VII concludes with recommendations for both policy and future research directions.

\section{BACKGROUND}

The literature on the origins and implications of financial crises characterized by sudden withdrawals of capital flows is extensive. Calvo (1998), Krugman (1999), Kaminsky and Reinhart (2000), and Desai (2003a) are among many noteworthy references. The literature may be categorized into three areas: (i) Self-fulfilling expectations (Chari and Kehoe, 2003; Aghion, Bacchetta, and Banerjee, 2001; Corsetti, Pesenti, and Roubini, 2001); (ii) Debtor's ability to repay (Cespedes, Chang, and Velasco, 2000; Caballero and Krishnamurthy, 2001); (iii) Debtor's willingness to repay (Eaton and Gersovitz, 1981; Bulow and Rogoff, 1989; Kehoe and Perri, 2000). Arellano and Mendoza (2002) provide a survey of the literature.

From a policy perspective, while the existing literature extensively discusses the implications of disciplined fiscal policy, it lacks formal models assessing the impact of disciplined fiscal policy on post-crisis recovery. ${ }^{6}$ Boughton (2001); Koptis (2000); Boorman, Lane, and others (2000); Chopra, Kang, and others (2001) discuss appropriate fiscal response to emerging market crisis. While, empirical evidence of non-Keynesian impacts of disciplined fiscal policy in industrialised countries is found in Alesina and Perotti (1995), Giavazzi and Pagano (1990), Giavazzi and Pagano (1996). See Hemming, Kell, and Mahfouz (2002) for a comprehensive review.

The connection between the post-crisis macroeconomic fiscal health of the government and the revenue-generating role of the private sector has played a key role in post-crisis recovery for many countries. For example, the improving fiscal performance of Brazil's government continues to contribute to foreign investors' positive outlook of Brazil's private sector. By contrast, "Argentina does have incentives to settle [its sovereign debt]...not settling it is

\footnotetext{
${ }^{5}$ My findings also shed light on contrasts in recovery process across countries. Desai (2003b) and Park and Lee (2001) are some notable references in this area.

${ }^{6}$ The fiscal literature relating the revenue-generating behavior of private firms and fiscal policies does not specifically look at the intricacies of this relationship during times of crisis characterized by a sudden stop of capital flows.
} 
delaying many other things...without a deal, the country's bigger companies will be unable to raise money...."7

The crisis-recovery-related literature generally does not connect the post-crisis macroeconomic fiscal health of the government with the revenue-generating role of the private sector, or to the impact of this connection on potential foreign creditors' expectations relating to an economy's recovery prospects. ${ }^{8}$ The critical role of the connection between the government and the private sector is overlooked in the literature on post-crisis recovery. It tends to focus either on private sector resurgence or public sector revival. Desai and Mitra (2004) find that pre-crisis export sector strength has a greater impact on post-crisis recovery than fiscal health. However, the potential endogeneity of export sector strength and fiscal health was unaccounted for.

This paper extends the existing literature by providing two features missing in crisis analysis, namely the interactive link between the government and the private sector, and an empirically applicable theoretical framework for examining the impact of fiscal policy on post-crisis recovery. The analysis assumes crisis (characterized by sudden withdrawals of capital flows) has already struck, regardless of the economic mechanism behind its origin. Once crisis strikes, does disciplined fiscal policy improve or worsen the extent of economic damage and the time to recovery?

The general equilibrium model in this paper simulates an economy starting from the period crisis strikes and models the reaction of major economic variables such as interest rate, exchange rate, prices, and economic production as the economy recovers from the crisis. The fiscal policy tools in this model are the corporate tax rate and the quantity of sovereign debt. The recovery path is measured as the trajectory of each variable back to the model's steadystate values. The impact of disciplined fiscal policy is measured by divergence (in both magnitude and time) of the recovery paths of each variable from the model where no fiscal policy is applied.

The model compares the reactions to disciplined fiscal policy of two post-crisis economies that differ only by one important structural distinction. One economy is more flexible than the other in the production process, allowing the firm to substitute domestic inputs for imported inputs in the production of the tradable good. The firm in the other economy, by contrast, has less flexibility in substituting domestic inputs for imported inputs. Although the model is theoretical, examples of two such economies that differ in the ability of firms to

\footnotetext{
7 “Argentina: A Serious Country?” The Economist, June 5-11, 2004, p. 9 of Survey.

${ }^{8}$ Caballero and Krishnamurthy (2004) is an exception. Their model has a limited amount of foreign credit available to emerging market borrowers (firms and government). When the government increases sovereign debt, it crowds out private investors and reduces the return on private investment, resulting in a decline of the total pool of foreign credit available for the firm and the government. While my model is similar in spirit to Caballero and Krishnamurthy (2004), my model provides a richer framework derived from microfoundations. This permits examination of crucial links between the government and the private sector, missing in Caballero and Krishnamurthy (2004), that apply even in the absence of sovereign debt.
} 
substitute domestic inputs for imported inputs and that also differ in their post-crisis recovery paths, despite both having followed disciplined fiscal policy, are Korea and Thailand. Korean firms are better able to substitute domestic inputs for imported inputs than Thai firms.

The link between the government and the private sector is modeled as a circular relationship where tax revenue is a significant determinant of the government's fiscal status and its sovereign debt premiums. Lower (higher) sovereign debt premiums inspire (damage) confidence among foreign creditors, who come forward with renewed (reduced) lending to the private sector and thus enhance (delay) the recovery process. The model simulations illustrate the starkly contrasting recovery patterns associated with disciplined fiscal policy. When the private sector has flexible production capacities, meaning firms can easily substitute domestic inputs for imported inputs, the firms adjust to the recessionary environment, sustain their activity, and thus continue contributing to the government's tax revenue, which in turn reduces the government's sovereign debt premiums. Despite its negative impact via traditional channels, disciplined fiscal policy facilitates economic recovery by enhancing the positive circular relationship between the government and the private sector. By contrast, when private sector production capacities are less flexible, firms are unable to provide the government with adequate tax revenue. Disciplined fiscal policy leads to higher sovereign debt premiums, creates a negative circular relationship between the government and the private sector, and slows the recovery process.

\section{THE MODEL}

The model is defined in infinite time by the following five agents and their behavioral specifications stated in Sections III.A-III.E: a representative household, a final goods firm, an intermediate goods firm, the government, a financial intermediary, and a foreign creditor. The relationships between agents in equilibrium are set out in Section III. All agents discount their future welfare at the same constant rate, $\beta$.

The recovery process is modeled as beginning from the moment a crisis strikes. Crises of the past decade have been characterized by sudden outflows of capital when an exogenous event causes the foreign creditor to lose confidence in the economy. Regardless of whether the crisis originates in the private or the public sector, the foreign creditor loses confidence in the economy causing the foreign creditor to suddenly:

- reduce valuation of the firm's collateral resulting in a binding collateral constraint for the firm; and

- reduce valuation of the government's collateral reflecting its uncertainty about the future revenue-generating capability of the government. Consequently, the foreign creditor only accepts the current tax revenue of the government as collateral, creating a binding sovereign debt constraint for the government.

In other words, a financial crisis is modeled as a time when the collateral constraint is suddenly binding for the firm, and the sovereign debt constraint is suddenly binding for the government.

The interaction between the two constraints will shape the severity of the crisis. A crisis originating in the private sector is defined as a time when the borrowing firm's collateral 
constraint becomes binding, making the sovereign debt constraint immediately binding as well. This implies that in the years before the onset of the crisis, the collateral constraint is not binding. For example, from 1990 to the first quarter of 1997, the collateral constraint with respect to foreign borrowing by East Asian firms was not binding. Similarly, a crisis originating in the public sector is modeled as a time when the government's sovereign debt constraint becomes binding, making the collateral constraint immediately binding as well. ${ }^{9}$

\section{A. Households}

The representative infinitely-lived household maximizes its utility subject to a budget constraint. The household consumes two types of goods, a consumption good the household purchases and a good produced by the government that is provided free of cost to the household. The household earns a wage in exchange for providing labor to firms (for the production of the tradable good and the nontradable good) and to the government (for the production of the government good). In each time, $t$, the household deposits, $D_{t}$, with the financial intermediary. In the following period, $t+1$, the household is returned its initial deposit with interest, $\left(1+r_{t}\right) D_{t}$. The household also owns shares in the firm producing intermediate goods. Each period, the household receives a dividend based on the profits of the firm in the previous period. In time, $t$, for example, the household will receive a dividend valued at $P_{t-1}^{T} \pi_{t-1}$, where $P_{t-1}^{T}$ is the price of the tradable good in time $t-1$, and $\pi_{t-1}$ is the dividend in time $t-1$. The household is endowed with a specific number of shares at time 0 and cannot trade or sell them at any point in time.

The household maximization problem is summarized as follows:

$$
\begin{gathered}
\max _{c_{t}, L_{t}, D_{t}} \quad \sum_{t=0}^{\infty} \beta^{t} \frac{\left[c_{t}^{b} g_{t}^{1-b}-\frac{\psi_{o}}{1+\psi} L_{t}^{1+\psi}\right]^{1-\sigma}}{1-\sigma} \\
\text { s.t. } \\
P_{t} c_{t} \leq W_{t} L_{t}-D_{t}+\left(1+r_{t-1}\right) D_{t-1}+P_{t-1}^{T} \pi_{t-1}
\end{gathered}
$$

$\underline{\text { FOC }}$

$$
\begin{aligned}
& L_{t}: \\
& \psi_{0} L_{t}^{\psi}=\frac{W_{t}}{P_{t}} b\left(\frac{g_{t}}{c_{t}}\right)^{1-b}
\end{aligned}
$$

${ }^{9}$ For example, from 1995 to mid-1997, the sovereign debt constraint was not binding with respect to the Russian government's sovereign debt despite a persistent high budget deficit of 7 percent of GDP because the foreign exchange reserves of the Russian central bank were perceived as adequate until the third quarter of 1997, during which the confidence of foreign holders of Russian government short-term bills was affected by the speculative impact of the Asian financial crisis (Desai, 2000). 


$$
\begin{aligned}
& D_{t}: \\
& \quad u_{c, t}=\beta \frac{P_{t}}{P_{t+1}} u_{c, t+1}\left(1+r_{t}\right)
\end{aligned}
$$

where,

$$
u_{c, t}=b\left(\frac{g_{t}}{c_{t}}\right)^{1-b}\left[c_{t}^{b} g_{t}^{1-b}-\frac{\psi_{0}}{1+\psi} L_{t}^{1+\psi}\right]^{-\sigma}
$$

Define:

$c_{t}=$ consumption good purchased by the household in period $t$;

$P_{t}=$ price of $c_{t}$ in period $t$

$g_{t}=$ good produced by the government in period $t$ that is provided free of cost to the household;

$W_{t}=$ wage earned by household in exchange for providing labor to firms in period $t$;

$L_{t}=$ labor provided by household to firms in period $t$;

$y_{t}^{N}=$ nontradable good in period $t$;

$D_{t}=$ deposit made by the household with the financial intermediary in period $t$;

$r_{t}=$ domestic interest rate in period $t$;

$P^{T}{ }_{t}=$ price of the tradable good in period $t$;

$\pi_{t}=$ dividend transferred from the intermediate goods firm to the household in period $t$;

$\beta, b, \psi, \sigma$ represent parameters that are treated as constants in this model. Their values are specified in section $\mathrm{V}$.

The solution to the household's maximization problem yields two first-order conditions. Equation (3) provides the household's labor supply. The amount of labor provided by the household is positively correlated with the real wage earned by the household, and negatively correlated with consumption because at a given moment in time the household has to choose between consuming or providing labor. Equation (4) demonstrates that the household will choose levels of consumption, deposits, and labor, such that the marginal utility of another unit of consumption today is equal to the marginal cost of a unit of consumption foregone tomorrow.

\section{B. Firms}

There are two types of firms: a final goods firm and an intermediate goods firm. ${ }^{10}$ In this

${ }^{10}$ Christiano, Gust, and Roldos (2004) use this framework for modeling firm behavior and for analyzing the effect (on collateral values rather than on post-crisis recovery) of monetary policy via a monetary authority that can regulate domestic interest rates by varying money supply. A lower interest rate leading to exchange rate depreciation can damage a firm's collateral. On the other hand, a nominal interest rate cut leading to a decline in real interest rate raises asset and collateral values for firms. If the impact of an interest rate cut is greater for asset values than for exchange rates, borrowing by firms increases, and the economy expands. Whether the interest rate cut has a greater impact on the exchange rate or on asset valuation depends on the economy's flexibility, which is defined as the degree of 
model the intermediate goods firm drives the results of the private sector. Identical model results may be derived by combining the final goods firm with the intermediate goods firm. However, the analysis is clearer when the model is derived using two separate firms.

\section{Final Goods Firm}

The final goods firm purchases and combines two types of intermediate goods (tradable good and nontradable good) to produce the final consumption good. The final goods firm does not undertake any investment activities.

$$
\max _{c_{t}^{T}, c_{t}^{N}} \quad \sum_{t=0}^{\infty} \beta^{t}\left(P_{t} c_{t}-P_{t}^{T} c_{t}^{T}-P_{t}^{N} c_{t}^{N}\right)
$$

s.t.

$$
c_{t}=\left(\left[(1-\gamma) c_{t}^{T}\right]^{\frac{\eta-1}{\eta}}+\left[\gamma c_{t}^{N}\right]^{\frac{\eta-1}{\eta}}\right)^{\frac{\eta}{\eta-1}}
$$

$\underline{\text { FOC }}$

Combining the FOC wrt $c_{t}^{N}, c_{t}^{T}$ :

$$
\begin{aligned}
\frac{P_{t}^{N}}{P_{t}^{T}} & =\frac{\gamma}{1-\gamma}\left(\frac{(1-\gamma) c_{t}^{T}}{\gamma c_{t}^{N}}\right)^{\frac{1}{\eta}} \\
\text { Let } \quad p_{t}^{N} & =\frac{P_{t}^{N}}{P_{t}^{T}}
\end{aligned}
$$

Combining (6) and (7):

$$
p_{t}=\left(\left(\frac{1}{1-\gamma}\right)^{1-\eta}+\left(\frac{p_{t}^{N}}{\gamma}\right)^{1-\eta}\right)^{\frac{1}{1-\eta}}
$$

substitutability between tradable and nontradable goods in the production of final consumption goods. Higher substitutability implies greater flexibility. I use the ChristianoGust-Roldos framework, without an active monetary policy, for constructing a model in which an emerging market economy recovers from a financial crisis. A key component of my model is the government sector missing in the Christiano-Gust-Roldos framework simply because they are interested in analyzing the impact of monetary policy on collateral values rather than on post-crisis recovery. The inclusion of government in my model also allows me to analyze the impact of the presence of large bureaucracies in emerging markets in their post-crisis recovery. 
Define:

$c_{t}^{T}=$ tradable good purchased by final goods firm in period $t$;

$c_{t}^{N}=$ nontradable good purchased by final goods firm in period $t$;

$c_{t}=$ final consumption good in period $t$;

$P_{t}^{T}=$ price of tradable good in period $t$

$P_{t}^{N}=$ price of nontradable good in period $t$;

$P_{t}=$ price of final consumption good in period $t$.

$\beta, \gamma, \eta$ represent parameters that are treated as constants in this model. Their values are specified in section $\mathrm{V}$.

Equation (7), combines the two first-order conditions to derive an expression for the relative demand of the nontradable good. The higher the price of the nontradable good relative to the price of the tradable good (lefthand side of equation (7)), the lower the demand by the final goods firm for the nontradable good (righthand side of equation (7)). Note that the price of the nontradable good relative to the price of the tradable good is the inverse of the real exchange rate (represented by the price of the nontradable good relative to the price of the tradable good). Equation (8) defines the price of the final good in terms of the real exchange rate.

\section{Intermediate Goods Firm}

The intermediate goods firm produces the tradable good and the nontradable good. The tradable good is produced using labor, capital, and an imported input. The nontradable good is produced using labor, and capital. The firm borrows short-term from the financial intermediary to finance its labor cost, $w_{t}\left(1+r_{t}\right)$. The firm borrows short-term from abroad to finance the cost of the imported input, $z_{t}\left(1+r^{*}\right) .{ }^{11}$ The firm also borrows long-term from abroad and pays interest of $r^{*} B_{t}$ on this debt. All payments of foreign debt are made using the tradable good. The firm is endowed with specific levels of capital in each sector at time $0, K^{T}$ and $K^{N}$. Capital does not depreciate, cannot be accumulated, and cannot be transferred across sectors.

The firm maximizes the total value of its dividends. Dividends are defined as the profits of the firm. The firm receives revenue from selling the tradable good both to the domestic final goods firm and to foreign firms. The firm also sells the nontradable good to the final goods firm. All prices are normalized by dividing prices by the price of the tradable good $P^{T}{ }_{t}$. Thus, $p^{N}{ }_{t}=P^{N}{ }_{t} / P^{T}{ }_{t}$ and $w_{t}=W_{t} / P^{T}{ }_{t}$, and so on. From here on, all prices in lower case letters indicate prices relative to the price of the tradable good.

The outlays of the firm include taxes, production costs, and interest and debt repayment. The firm pays taxes on sales of the tradable good. As described above, the production costs of the firm consist of labor cost, $w_{t}\left(1+r_{t}\right)$, and cost for the imported input $z_{t}\left(1+r^{*}\right)$. In period $t$, the firm pays interest on its long-term foreign debt, $r^{*} B_{t}$, and takes on new debt of $B_{t+1}$. The noPonzi game condition (equation (14)) is imposed so that the present value of long-term debt equals zero.

${ }^{11}$ The intermediate firm is dependent on imported inputs that can only be purchased with foreign credit. In reality, even when imported inputs are financed with domestic resources, some short-term credit with foreign creditors is necessary for transactional purposes. 
Finally, the intermediate goods firm has an additional constraint. In times of crisis, the value of its assets, from the perspective of the foreign creditor, must be at least as large as the value of its liabilities. This constraint, shown in equation (15), is called the collateral constraint. ${ }^{12}$

The foreign creditor is aware that during crisis he may not be able to access all the capital of the intermediate goods firm. Consequently, the foreign creditor only accepts a percentage $\tau_{t}$ of the value of the intermediate goods firm's capital $q_{t}^{i} K^{i}(i=\mathrm{T}, \mathrm{N})$ as collateral. The percentage of the value of the intermediate goods firm's capital accepted as collateral is endogenously determined. Details are given in Section III.E describing the foreign creditor.

$$
\begin{aligned}
& \max _{B_{t+1}, Z_{t}, L_{t}^{T}, L_{t}^{N}} \sum_{t=0}^{\infty} \beta^{t} \Lambda_{t+1} \pi_{t} \\
& \text { s.t. } \\
& \pi_{t}=p_{t}^{N} y_{t}^{N}+\left(1-\rho_{\mathrm{t}}\right) y_{t}^{T}-w_{t}\left(1+r_{t}\right)\left(L_{t}^{N}+L_{t}^{T}\right) \\
& -\left(1+r^{*}\right) z_{t}-r^{*} B_{t}+\left(B_{t+1}-B_{t}\right) \\
& y_{t}^{T}=\left(\theta\left[\mu_{1} V_{t}\right]^{\frac{\xi-1}{\xi}}+(1-\theta)\left[\mu_{2} z_{t}\right]^{\frac{\xi-1}{\xi}}\right)^{\frac{\xi}{\xi-1}} \\
& V_{t}=A\left(K^{T}\right)^{v}\left(L_{t}^{T}\right)^{1-v} \\
& y_{t}^{N}=\left(K^{N}\right)^{\alpha}\left(L_{t}^{N}\right)^{1-\alpha} \\
& \frac{B_{t+1}}{\left(1+r^{*}\right)^{t}} \rightarrow \quad 0 \\
& \text { as } t \rightarrow \infty \\
& \tau_{t}^{N} q_{t}^{N} K^{N}+\tau_{t}^{T} q_{t}^{T} K^{T} \geq\left(1+r^{*}\right) z_{t}+\left(1+r^{*}\right) B_{t}+w_{t}\left(1+r_{t}\right)\left(L_{t}^{N}+L_{t}^{T}\right)
\end{aligned}
$$

$\underline{\text { FOC }}$

$$
\begin{aligned}
& B_{t+1}: \\
& \quad \Lambda_{t+1}=\beta \Lambda_{t+2}\left(1+r^{*}\right)\left(1+\lambda_{t+1}\right)
\end{aligned}
$$

12 This constraint is not binding during normal times. For example, the firm's potential output can also be considered as collateral in non-crisis times. By contrast, from the perspective of the foreign creditor, lending to a firm with a poor balance sheet or with recent inability to pay its debts is risky during a crisis. 


$$
\begin{gathered}
z_{t}: \\
\left(1+r^{*}\right)\left(1+\lambda_{t}\right)=\left(1-\rho_{t}\right)(1-\theta) \mu_{2}\left(\frac{y_{t}^{T}}{\mu_{2} z_{t}}\right)^{\frac{1}{\xi}} \\
L_{t}^{T}: \\
w_{t}\left(1+r_{\mathrm{t}}\right)\left(1+\lambda_{t}\right)=\left(1-\rho_{t}\right) \theta \mu_{1}(1-v)\left(\frac{y_{t}^{T}}{\mu_{1} V_{t}}\right)^{\frac{1}{\xi}} \\
L_{t}^{N}: \\
w_{t}\left(1+r_{t}\right)\left(1+\lambda_{t}\right)=p_{t}^{N}(1-\alpha) \frac{y_{t}^{N}}{L_{t}^{N}}
\end{gathered}
$$

Define:

$z_{t}=$ imported input employed in production of tradable good in period $t$;

$L_{t}{ }^{T}=$ labor employed in production of tradable good in period $t$;

$K^{T}=$ capital employed in production of tradable good;

$L_{t}^{N}=$ labor employed in production of nontradable good in period $t$;

$K^{N}=$ capital employed in production of nontradable good;

$w_{t}=$ real wage paid to labor $\left(w_{t}=W_{t} / P_{t}^{T}\right)$ in period $t$;

$r^{*}=$ foreign interest rate;

$B_{t}=$ intermediate goods firm's long-term foreign debt in period $t$;

$\Lambda_{t+1}=$ price per unit dividend in period $t$;

$\rho_{t}=$ taxes paid to the government by the intermediate goods firm in period $t$, expressed as a percent of sales of the tradable good;

$\lambda_{t}=$ shadow value of another unit of long-term foreign debt;

$\tau^{N}{ }_{t}=$ percentage of physical capital employed in production of nontradable good that foreign creditor is willing to accept as collateral in period $t$;

$\tau^{T}{ }_{t}=$ percentage of physical capital employed in production of tradable good that foreign creditor is willing to accept as collateral in period $t$;

$q_{t}^{N}=$ per unit value of capital employed in production of nontradable good in period $t$;

$q_{t}^{T}=$ per unit value of capital employed in production of tradable good in period $t$.

$\beta, \theta, \mu_{1}, \mu_{2}, \xi, v, \alpha$ represent parameters that are treated as constants in this model. Their values are specified in section $\mathrm{V}$.

The first-order conditions describe the amounts of foreign debt, imported input, and labor the firm chooses to employ such that the marginal benefits of employing another unit of each of these ressources is equal to its marginal cost. Equation (16) states that the marginal benefit from undertaking another unit of foreign debt today (left hand side of equation (16)) is equal to the marginal cost of holding another unit of foreign debt tomorrow (righthand side of equation (16)). In equation (17), the marginal cost today from purchasing another unit of imported input (lefthand side of equation (17)) is equal to the marginal benefit today from employing another unit of imported input. Similarly, equations (18) and (19) equate the marginal cost today of purchasing another unit of labor to the marginal benefit today of 
employing another unit of labor.

\section{Government}

The government's main interest is to maximize the welfare of the household through selection of the tax rate (and hence, the production of a government good that is essential to household consumption), and sovereign debt levels. The consumption good produced by the government is given for free to the household. The government good is produced using labor (equation (23)). The government's exclusive use of labor in production reflects the large government bureaucracy in most emerging market economies.

The government good may include items ranging from law and order to health care benefits. If the government is unable to produce this good, the economy may collapse. Without a minimal amount of the government good, the utility of the household will drop suddenly, propagating a negative shock throughout the economy. In other words, when the government good falls below a particular level, the marginal utility of the household explodes, resulting in volatile interest rates and prices. For example, if the government is no longer able to provide a minimal amount of law and order, individuals will be rioting in the streets, as was observed in Argentina during 2001-02.

The production of the government good is financed through tax revenue and debt. The government receives revenues from taxes paid on the production of the tradable good, $\rho_{t} y^{T}{ }_{t}$. The government borrows short-term from the domestic financial intermediary to pay for labor, $w_{t}\left(1+r_{t}\right) L_{t}^{G}$. To bridge the gap between revenues and expenditures, the government borrows long-term from abroad. In each period $t$, the government borrows $Q_{t+1}$ from abroad and makes interest payments of $r^{*} Q_{t}$ on its long-term debt, all denominated in terms of the tradable good. Long-term domestic debt is ruled out.

During a crisis, in a given period, the government must repay all its liabilities (current shortterm debt and previous long-term debt including interest) with its current revenues. In other words, the sum of all government expenditures will be less than or equal to revenues. This constraint in equation (25) represents the sovereign debt constraint in the model. ${ }^{13,14}$

In combination with the government's budget constraint (equation 24), the sovereign debt constraint implies that the government cannot take on additional sovereign debt.

Consequently, the value of sovereign debt in all periods following the onset of crisis (i.e., the

${ }^{13}$ Modeling the public sector with this type of constraint differs from typical models of sovereign debt crisis, which involve modeling the government's willingness to repay sovereign debt. Obstfeld and Rogoff (1996) provide a nice summary of the basic models of sovereign debt. My modeling technique differs from standard models in order to create and emphasize the importance of the interactive link between the constraints placed on the government and the private sector during times of crisis.

${ }^{14}$ This constraint is not binding in normal times, during which the foreign creditor may be willing to lend to a government in poor fiscal standing. During a crisis, however, the risk involved in lending to a government with poor fiscal standing or with a recent debt default is too high. 
period when the sovereign debt constraint becomes binding) is zero.

In reality, sovereign lending is brought to a halt during crisis. As was seen in Argentina (2001-02), when crisis hits, governments pay back whatever debt they can at that moment. The remainder of the debt is forgiven or suspended and almost no sovereign debt is issued until recovery is well underway. ${ }^{15}$ Similarly in this model, in periods after a crisis strikes, the government does not issue any further sovereign debt until recovery is complete.

$$
\begin{gathered}
\max _{Q_{t+1}, \rho_{t}} \quad \sum_{t=0}^{\infty} \beta^{t} \frac{\left[c_{t}^{b} g_{t}^{1-b}-\frac{\psi_{0}}{1+\psi}\left(L_{t}^{N}+L_{t}^{T}+L_{t}^{G}\right)^{1+\psi}\right]^{1-\sigma}}{1-\sigma} \\
\text { s.t. } \\
P_{t} c_{t} \leq W_{t} L_{t}-D_{t}+\left(1+r_{t-1}\right) D_{t-1}+P_{t-1}^{T} \pi_{t-1} \\
\pi_{t-1}=p_{t-1}^{N} y_{t-1}^{N}+\left(1-\rho_{t-1}\right) y_{t-1}^{T}-w_{t-1}\left(1+r_{t-1}\right)\left(L_{t-1}^{N}+L_{t-1}^{T}\right) \\
g_{t}=\left(1+r^{*}\right) z_{t-1}-r^{*} B_{t-1}+\left(B_{t}-B_{t-1}\right) \\
-\left(Q_{t+1}-L_{t}\right) \quad=\quad \rho_{t} y_{t}^{T}-\left(1+r^{*}\right) w_{t} L_{t}^{G}-r^{*} Q_{t} \\
\rho_{t} y_{t}^{T} \geq \quad\left(1+r_{t}\right) w_{t} L_{t}^{G}+\left(1+r^{*}\right) Q_{t}
\end{gathered}
$$

$\underline{\text { FOC }}$

$$
\begin{aligned}
Q_{t+1}: & \\
\lambda_{t}^{G}= & \frac{1}{\left(1+r_{t}\right) w_{t}}\left(u_{c, t} \frac{W_{t}}{P_{t}}+u_{g, t} \varphi\left(L_{t}^{G}\right)^{\varphi-1}-u_{L^{G}, t}\right) \\
& -\beta \frac{\left(1+r^{*}\right)}{\left(1+r_{t+1}\right) w_{t+1}}\left(u_{c, t+1} \frac{W_{t+1}}{P_{t+1}}+u_{g, t+1} \varphi\left(L_{t+1}^{G}\right)^{\varphi-1}-u_{L^{G}, t+1}\right)
\end{aligned}
$$


$\rho_{t}:$

$$
\begin{aligned}
& \frac{y_{t}^{T}}{\left(1+r_{t}\right) w_{t}}\left(u_{c, t} \frac{W_{t}}{P_{t}}+u_{g, t} \varphi\left(L_{t}^{G}\right)^{\varphi-1}-u_{L^{G}, t}\right) \\
& =\quad \beta u_{c, t+1} \frac{P_{t}^{T}}{P_{t+1}} y_{t}^{T}
\end{aligned}
$$

Where,

$$
\begin{aligned}
u_{c, t} & =b\left(\frac{g_{t}}{c_{t}}\right)^{1-b}\left[c_{t}^{b} g_{t}^{1-b}-\frac{\psi_{0}}{1+\psi}\left(L_{t}^{N}+L_{t}^{T}+L_{t}^{G}\right)^{1+\psi}\right]^{-\sigma} \\
u_{g, t} & =(1-b)\left(\frac{c_{t}}{g_{t}}\right)^{b}\left[c_{t}^{b} g_{t}^{1-b}-\frac{\psi_{0}}{1+\psi}\left(L_{t}^{N}+L_{t}^{T}+L_{t}^{G}\right)^{1+\psi}\right]^{-\sigma} \\
u_{L^{G}, t} & =\psi_{0}\left(L_{t}^{N}+L_{t}^{T}+L_{t}^{G}\right)^{\psi}\left[c_{t}^{b} g_{t}^{1-b}-\frac{\psi_{0}}{1+\psi}\left(L_{t}^{N}+L_{t}^{T}+L_{t}^{G}\right)^{1+\psi}\right]^{-\sigma}
\end{aligned}
$$

Define:

$L_{t}^{G}=$ labor employed to produce government good in period $t$;

$Q_{t+1}=$ government borrowing from abroad in period $t$;

$\lambda^{G}{ }_{t}=$ shadow value of another unit of long-term borrowing from abroad;

$\varphi$ represents a parameter that is treated as a constant in this model. Its value is specified in section $\mathrm{V}$.

The first-order conditions describe the optimal selections of a corporate tax rate and amount of sovereign debt for the government. Equation (26) states that the marginal benefit of holding another unit of sovereign debt today (lefthand side of the equation) is equal to the marginal cost tomorrow of this unit of sovereign debt (righthand side of the equation). In equation (27), the marginal benefit today of increasing the tax rate (lefthand side of the equation) is equal to the marginal cost suffered by the government tomorrow of having increased the tax rate in the previous period (righthand side of the equation).

\section{Domestic Financial Intermediary}

The domestic financial intermediary is a passive lender setting its supply of funds equal to the demand for funds. It receives deposits from the household and lends the cash to the intermediate goods firm and the government so they can pay for labor. At each moment in time,

$$
D_{t}=W_{t}\left(L_{t}^{N}+L_{t}^{T}+L_{t}^{G}\right)
$$

The domestic interest rate is endogenously determined. The domestic interest rate is determined by the demand and supply of loanable funds. The intermediate goods firm and the government drive the demand for loanable funds. The supply of loanable funds is 
determined by the deposits of the household. ${ }^{16}$

\section{E. Foreign Creditor}

The foreign creditor lends short-term and long-term to the intermediate goods firm and lends only long-term to the government. During the non-crisis phase, the foreign creditor will lend large amounts to the intermediate goods firm, accepting even output as collateral. During times of crisis, when lending to the intermediate goods firm the foreign creditor accepts only a portion, $\tau$, of physical assets as collateral. This reflects the foreign creditor's judgment that it may not be possible to recover or make use of all the physical collateral if the firm defaults-the extreme case being if the economy as a whole collapses.

If the economy collapses, the government will impede the foreign creditor's access to the physical assets of the firm because the loss of the firm's physical assets to the foreign creditor will only exacerbate economic collapse. In particular, the government will impose a tax on any physical assets the foreign creditor retrieves from the economy. This is similar to taxes on capital outflows that have been observed in emerging market countries during the recent series of crises.

The tax on the foreign creditor's retrieval of a firm's physical assets, exogenously determined by the government, is a function of the shadow value of sovereign debt. The shadow value of the government's sovereign debt constraint, $\lambda^{G}{ }_{t}$, can be interpreted as the value to the government of one more unit of sovereign debt, or the premium the government is willing to pay for another unit of sovereign debt. When the shadow value of sovereign debt is high, the government is desperate to borrow in order to continue production of the essential government good. During a crisis, the government must continue production of the essential government good, despite the decline in tax revenues. Consequently, the value to the government of one more unit of sovereign debt increases.

The foreign creditor defines the portion of the firm's assets he is willing to accept as collateral as a function of the tax charged by the government on the foreign creditor's retrieval of the firm's assets. Where as described in the previous paragraph, the tax charged by the government is a function of the shadow value of sovereign debt. The foreign creditor is generally aware of a government's implicit valuation of sovereign debt. This is a reasonable assumption since most foreign creditors to emerging market governments are large institutional investors. This class of investors has the resources necessary to closely monitor the financial status, and in particular, the sovereign debt valuation (or premium) of any emerging economy government.

\footnotetext{
${ }^{16}$ In current research, I am investigating the interactions between monetary and fiscal policy in a model with an exogenously imposed monetary rule. In that version of the model, the monetary authority injects liquidity into the system through the domestic financial intermediary, as in Christiano, Gust, and Roldos (2004). The domestic financial intermediary is modeled as lending money to both firms and the government from the funds it receives from household deposits and currency transfers from the monetary authority, that is, $D_{t}+X_{t}$ $=W_{t}\left(L^{N}{ }_{t}+L^{T}{ }_{t}+L^{G}{ }_{t}\right)$, where $X_{t}$ is the transfer of currency from the monetary authority to the domestic financial intermediary.
} 
In the event of economic collapse resulting from the government's inability to provide the essential government good, the higher the shadow value of sovereign debt, the more severe the collapse. A higher shadow value of sovereign debt results in a higher tax on the foreign creditor's retrieval of a firm's physical assets, and a lower percentage of a firm's physical assets accepted as collateral by the foreign creditor. Where,

$$
\tau_{t}=1-\frac{\lambda_{t}^{G}}{\lambda_{\max }^{G}}
$$

$\frac{\lambda_{t}^{G}}{\lambda_{\max }^{G}}$ represents the tax charged by the government. ${ }^{17}$

The government has a predetermined maximum premium it is willing to pay for sovereign debt. ${ }^{18}$ The closer the shadow value of sovereign debt is to the maximum premium, the greater the damage incurred if there is economic collapse, and thus, the higher the percentage of a firm's physical assets the government would like to retain. ${ }^{19}$

As government finances improve, the value of borrowing another unit from abroad decreases. In this context, the tax charged to the foreign creditor in the event of economic collapse declines. The foreign creditor, acquiring greater confidence in the economy, raises the valuation of the intermediate goods firm's assets, and therefore is willing to lend the intermediate goods firm more.

\section{EQUILIBRIUM CONDITIONS}

Equilibrium is defined as the first-order conditions for all agents of the economy combined with the equilibrium conditions described below.

The total labor supplied in the economy must equal the sum of labor employed:

$$
L_{t}=L_{t}^{N}+L_{t}^{T}+L_{t}^{G}
$$

${ }^{17}$ An alternative specification of $\tau_{t}$ yielding the same qualitative results is:

$\tau_{t}=1-h \frac{\lambda_{t}^{G}}{\lambda_{\max }^{G}}$,

where $h$ is the sensitivity of the foreign creditor to the tax charged by the government in the event of economic collapse. When $h>0$, the results of the model remain qualitatively the same. For simplicity, I present the case where $h=1$. That is, for a 1 percent increase in tax, there is a 1 percent decrease in the percentage of physical assets accepted as collateral by the foreign creditor.

18 This premium reflects the maximum sovereign debt premiums emerging market countries have been willing to pay in the past decade, as measured by indices such as JP Morgan's EMBI+.

${ }^{19}$ Damage from economic collapse is greater with a higher shadow value of sovereign debt because the sudden loss of the essential government good is greater in this situation. 
In equilibrium, the domestic financial intermediary will lend as much as it receives, as explained in Section III.D describing the domestic financial intermediary (equation (28)).

$$
D_{t}=W_{t} L_{t}
$$

The market for the tradable good must clear. This is represented by the equation below, where the LHS is the change in net foreign assets. The RHS is the current account.

$$
-\left(B_{\mathrm{t}+1}-B_{t}\right)-\left(Q_{\mathrm{t}+1}-Q_{t}\right)=\left(1-\rho_{t}\right) y_{t}^{T}-\left(1+r^{*}\right) z_{t}-r^{*} B_{t}-r^{*} Q_{t}-c_{t}^{T}
$$

The market for the nontradable good must clear:

$$
y_{t}^{N}=c_{t}^{N}
$$

In equilibrium, the price per dividend equals the marginal utility of one unit of dividend. The marginal utility of one unit of dividend (referring to the household's maximization problem) is:

$$
M U_{\pi, t}=\beta u_{c, t+1} \frac{1}{p_{t+1}} \frac{P_{t}^{T}}{P_{t+1}^{T}}
$$

Thus, the value of one unit of dividend is:

$$
\Lambda_{t+1}=\beta u_{c, t+1} \frac{1}{p_{t+1}} \frac{P_{t}^{T}}{P_{t+1}^{T}}
$$

Combining the household's Euler equation (4), the intermediate goods firm's FOC with respect to $B_{t+1}$, equation (16), the value of one unit of dividend, equation (34), an expression for interest rate parity is derived:

$$
R_{t+1}=\frac{P_{t+1}^{T}}{P_{t}^{T}}\left(1+r^{*}\right)\left(1+\lambda_{t+1}\right)
$$

Combining the budget constraint of the household, equation (2), the definition of the dividend, equation (10), the value of one unit of dividend, equation (34), the government's budget constraint, equation (24), and the current account equation (31), the following equation is obtained, relating the values of goods consumed in the following period with those produced in the current period:

$$
p_{t+1} \frac{P_{t+1}^{T}}{P_{t}^{T}} c_{t+1}=p_{t}^{N} y_{t}^{N}+\rho_{t} y_{t}^{T}+c_{t}^{T}
$$

The model described consists of a system of 23 equations in 23 variables derived from the first order conditions and the equilibrium conditions described above.

The initial steady-state reflects pre-crisis equilibrium where the collateral and sovereign debt 
constraints are marginally nonbinding. Once the collateral and sovereign debt constraints become binding, all variables adjust over time moving toward the final steady-state.

Configurations of steady-state variables and derivations of the paths from the initial steadystate to the final steady-state are available in a technical appendix provided upon request.

\section{Parameters}

Since the model described in Section III has no known closed-form solution, numerical approximations are applied to understand the behavior of major macroeconomic variables in this economy. In particular, the behavior of production (in government, tradable, and nontradable goods sectors), the nominal exchange rate, the price level, the domestic interest rate, the tax rate, and capital inflows are of interest. The parameter values applied in the calibration of the model are presented in Table 1.

Parameter values were selected to represent the average emerging market economy. All parameter values pertaining to firms and the household were chosen to approximate an average of estimated values for Argentina (Uribe, 1997; Rebelo and Vegh, 1995) and Korea (Christiano, Gust, and Roldos, 2004), the two countries representing two extremes in the spectrum of emerging market crises experiences. ${ }^{20}$ The maximum premium the government pays for sovereign debt is calculated from JP Morgan's EMBI+ and Global data on Argentina and Korea. The risk-free interest rate is approximately the average U.S. short-term lending rate over 1996-2001.

${ }^{20}$ The criteria for parameter selection included yielding smooth results. Consequently, the parameters were chosen to be close to the average of estimated values for Argentina and Korea but are not always exactly the average of the two. 
Table 1. Parameter Values for Model Calibration

\begin{tabular}{|c|c|c|c|}
\hline Parameter & Interpretation & $\begin{array}{c}\text { Flexibility } \\
\text { in } \\
\text { Production } \\
\end{array}$ & $\begin{array}{c}\text { Less } \\
\text { Flexibility } \\
\text { in } \\
\text { Production } \\
\end{array}$ \\
\hline$b$ & Share of the private good in household consumption & 0.71 & 0.73 \\
\hline$\psi_{o}$ & $\begin{array}{l}\text { Parameter for share of household's time spent working in } \\
\text { steady-state }\end{array}$ & 2.44 & 2.78 \\
\hline$\Psi$ & Inverse of elasticity of labor supply & 2.09 & 2 \\
\hline$\sigma$ & $\begin{array}{l}\text { Inverse of intertemporal elasticity of substitution in } \\
\text { consumption }\end{array}$ & 0.8 & 0.8 \\
\hline$g$ & $\begin{array}{l}\text { Share of the nontradable good in final consumption good } \\
\text { production }\end{array}$ & 0.5 & 0.5 \\
\hline$\eta$ & $\begin{array}{l}\text { Elasticity of substitution between the tradable and } \\
\text { nontradable good in final good production }\end{array}$ & 0.5 & 0.5 \\
\hline$\theta$ & $\begin{array}{l}\text { Share of domestic inputs in the production of the tradable } \\
\text { good }\end{array}$ & 0.56 & 0.56 \\
\hline$\mu_{1}$ & $\begin{array}{l}\text { Inverse of the share of domestic input's value added to } \\
\text { tradable good production under perfect complementarity }\end{array}$ & 1 & 1 \\
\hline$\mu_{2}$ & $\begin{array}{l}\text { Inverse of the share of imported input's value added to } \\
\text { tradable good production under perfect complementarity }\end{array}$ & 1 & 1 \\
\hline$\xi$ & $\begin{array}{l}\text { Elasticity of substitution between imported and domestic } \\
\text { inputs in tradable good production }{ }^{\text {a }}\end{array}$ & 2.46 & 0.87 \\
\hline$v$ & Share of capital in tradable good production & 0.5 & 0.5 \\
\hline$K^{T}$ & Capital in tradable good production & 1 & 1 \\
\hline$A$ & Technology parameter in tradable good production & 1.75 & 1.61 \\
\hline$K^{N}$ & Capital applied in nontradable good production & 1.89 & 1.92 \\
\hline$\alpha$ & Share of capital in nontradable good production & 0.27 & 0.29 \\
\hline$\phi$ & $\begin{array}{l}\text { Returns to scale parameter of labor in government good } \\
\text { production }\end{array}$ & 0.8 & 0.8 \\
\hline$\lambda_{\text {max }}^{\mathrm{G}}$ & Maximum premium the government pays for sovereign debt & 0.85 & 0.85 \\
\hline$r^{*}$ & Risk-free world interest rate & 0.06 & 0.06 \\
\hline$\beta$ & Discount rate $^{b}$ & 0.94 & 0.94 \\
\hline \multicolumn{4}{|c|}{$\begin{array}{l}\text { Notes: } \\
{ }^{a} \text { The qualitative result of the model simulation hold for different degrees of substitutability and lack thereof. } \\
\text { Other things being equal, the minimum difference in elasticities between the case of flexibility and that of less } \\
\text { flexibility in order for the model results to hold is } 1.03 \text {. The current elasticity parameters were selected to } \\
\text { highlight the contrast between the case of flexibility and less flexibility. } \\
{ }^{b} \beta=1 /\left(1+r^{*}\right) \text {. Agents in the economy discount at the steady-state interest rate, } r_{s s}=r^{*} \text {. }\end{array}$} \\
\hline
\end{tabular}

\section{Simulations}

This paper simulates the reaction of an economy to fiscal policy in the context of recovery from a financial crisis characterized by sudden withdrawals of foreign capital flows. In particular, the reactions to disciplined fiscal policy of two post-crisis economies that differ only by one important structural distinction are compared. One economy is more flexible than the other in the production process, allowing the firm to substitute domestic inputs for imported inputs in the production of the tradable good. The firm in the other economy, by contrast, has less flexibility in substituting domestic inputs for imported inputs.

The simulations proceed in the following steps: 
- The base case simulations demonstrate the recovery process of each type of economy in which the government targets a sustained zero percent budget surplus.

- Next, the government's fiscal policy in each type of economy is changed to one where the government targets a sustained 3 percent budget surplus. The simulations track the reactions of each type of economy to a 3 percent budget surplus compared to an economy with a zero percent budget surplus. ${ }^{21}$

As this paper concerns only the recovery process, the simulations of the zero-budget-surplus base case (stated immediately below) and of the 3-percent-budget-surplus case (following the base case) start in the period during which the collateral and sovereign debt constraints become binding for the firm and the government. ${ }^{22}$ The simulations show how the economy adjusts inputs and prices to the imposition of these constraints.

When there is flexibility in production, disciplined fiscal policy results in improved postcrisis economic recovery, measured by production (Figures 1,2,3), exchange rate depreciation (Figure 4), price level (Figure 5), interest rates (Figure 6), tax rates (Figure 7) and capital inflows (Figure 8). In contrast, disciplined fiscal policy applied to an economy with less flexibility in production has the opposite effect. Post-crisis recovery is weaker, with larger production losses (Figures 1, 2, 3), exchange rate depreciation (Figure 4), higher and more detrimental price levels (Figure 5), interest rates (Figure 6), tax rates (Figure 7), and lower capital inflows (Figure 8).

\section{A. The Base Case}

The base case simulations of the model resemble an emerging market economy and employ the parameters of Table 1. The time paths of the variables presented in Figures A.1 and A.3 in the Appendix qualitatively resemble those of emerging market economies that have recently experienced a financial crisis. ${ }^{23}$

When the collateral (equation 15) and the sovereign debt (equation 25) constraints suddenly become binding for the firm and the government respectively, they react by reducing the value of their liabilities relative to their assets in each period until the steady-state is reached. $^{24}$

\footnotetext{
${ }^{21}$ Qualitatively, the results of the simulation comparisons in this exercise are the same as simulations comparing a deficit target of -3 percent with a deficit target of -6 percent.

${ }^{22}$ In other words, I assume that the constraints are not binding in period zero. When the crisis strikes in period 1, the collateral and sovereign debt constraints become binding.

${ }^{23}$ Empirical examinations of major macroeconomic variables during recent financial crises is available in Calvo and Reinhart (2000), Milesi-Ferreti and Razin (2000), and Mendoza (2002).

${ }^{24}$ To be precise, in period zero, the constraints are not binding. In period 1 crisis strikes, the collateral and sovereign debt constraints become binding.
} 


\section{Government in the Base Case}

The shadow value of another unit of long-term debt abruptly rises for the government in the period in which it faces binding constraints. ${ }^{25}$ An additional unit of sovereign debt will allow greater production of the government good today, however, at the cost of higher gross interest payments and a more restrictive sovereign debt constraint, resulting in less production of the government good tomorrow.

In reaction to the high shadow value of another unit of long-term sovereign debt and the budget constraint, the government immediately refrains from taking on new sovereign debt. When the sovereign debt constraint is binding, the government must repay all its liabilities (both long-term and short-term) with its current revenues. In other words, the sum of all government expenditures will equal revenues. Along with the government's budget constraint, this implies that the government cannot take on additional sovereign debt. Consequently, the value of sovereign debt in all periods following the onset of a crisis (i.e., the period when the sovereign debt constraint becomes binding) is zero.

\footnotetext{
${ }^{25}$ When the sovereign debt constraint is not binding, the shadow value is zero. Thus, prior to the crisis, at time zero, the shadow value of sovereign debt is zero.
} 
Figures 1-8. Post-Crisis Paths, Under 3 Percent Budget Surplus Target
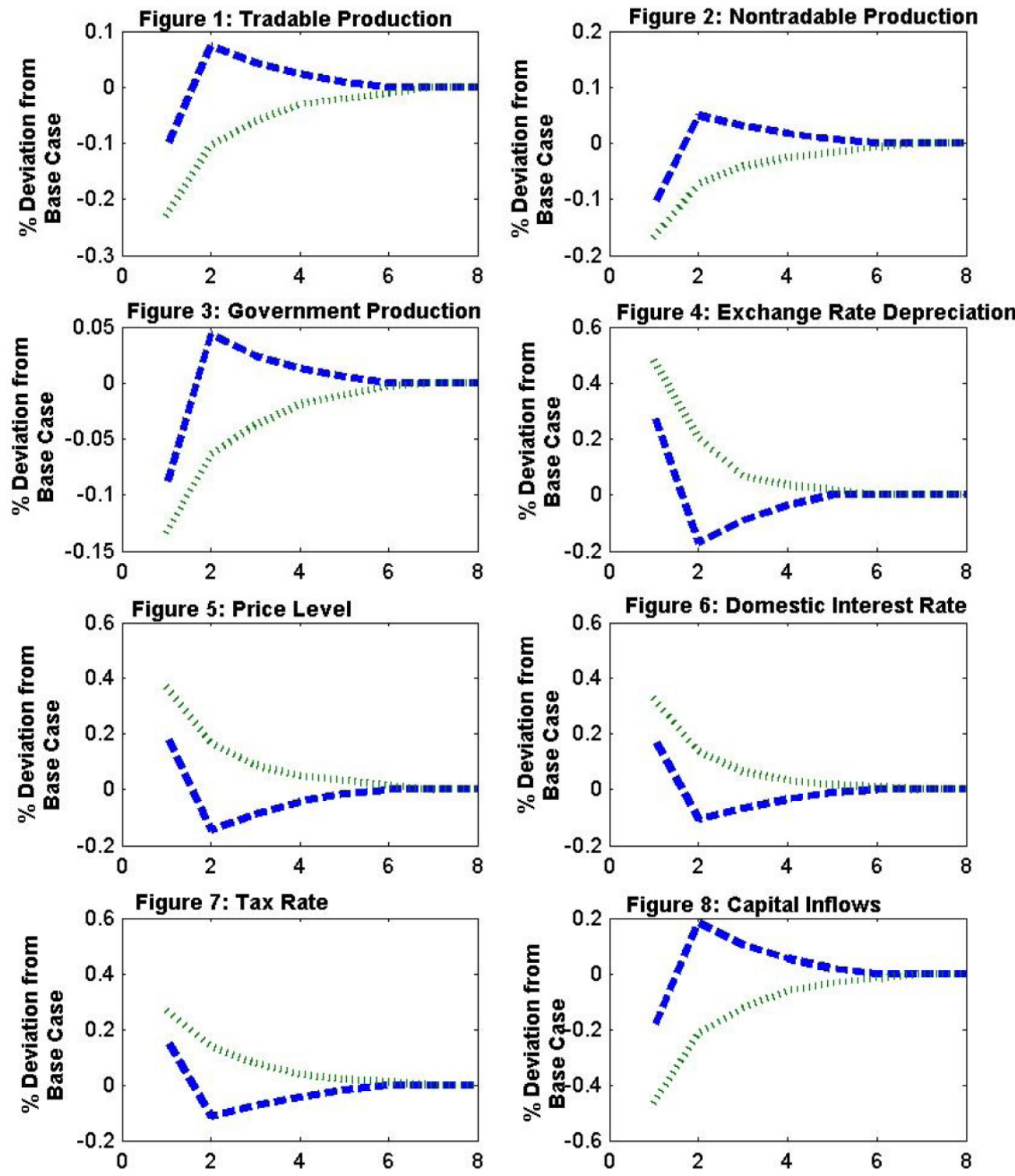

- Flexibility in Production Less Flexibility in Production

Notes:

1. Financial crisis strikes in period 1 when the government's and firm's debt constraints (defined in the text) become binding.

2. Periods 2 to 8 are post-crisis recovery periods.

3. The final steady-state is reached by period 6 in the simulations where the firm has flexibility in production. In the simulations where the firm has less flexibility in production, the final steady-state is reached by period 8 .

4. All variables are charted as percentage deviations from their base case values.

5. The base case represents post-crisis paths of variables where the government sustains a 0 percent budget surplus.

Source: Author's calculations. 
In addition to reducing sovereign debt, the government must also adjust the tax rate and employment in order to meet its sovereign debt constraint. In the period the constraints become binding, the government has a high level of sovereign debt and interest payments. ${ }^{26}$ On the other hand, the government's tax revenue declines significantly with the reduction in the production of the tradable good by the firm. To meet the binding sovereign debt constraint, the government increases the tax rate to improve revenues. It reduces domestic debt to finance labor costs, resulting in employment cutbacks in the production of the government good leading to a lower output of the government good. ${ }^{27}$ The decline in employment in the government sector, however, is not large when the initial level of sovereign debt is not excessive.

In the following periods, the government's tax base increases, as the firm increases its production of the tradable good. Consequently, the tax rate declines (Figures A.1.1 and A.3.1). With no new sovereign debt, the tax revenue is spent entirely on short-term domestic debt for labor. Employment (Figures A.1.2 and A.3.2), and production (Figures A.1.3 and A.3.3) in the government sector improve, gradually moving toward their higher steady-state values. ${ }^{28}$ With greater tax revenues, the government is also less desperate to borrow from abroad, reducing the shadow value of sovereign debt (Figures A.1.4 and A.3.4).

\section{Firms in the Base Case}

To meet the collateral constraint, the firm adjusts short-term and long-term debt, and employment in tradable and nontradable sectors. ${ }^{29}$ The period the collateral constraint becomes binding, the shadow value of another unit of long-term debt abruptly rises for the firm. ${ }^{30}$ For the firm, another unit of long-term foreign debt today has a dual cost. It will not only mean higher gross interest payments tomorrow, but tomorrow's collateral constraint will become more restrictive, resulting in lower profits. Thus, the benefit of higher profits today

${ }^{26}$ In this case, the sovereign debt refers to the sovereign debt the government carries over from the previous period when the sovereign debt constraint was not binding.

${ }^{27}$ The decline in wages helps the government reduce its labor costs. The increase in domestic interest rate, however, is larger than the decrease in wages, resulting in the inevitable decline in the employment of domestic labor for the production of the government good.

${ }^{28}$ When there is more substitutability between inputs in the production of the tradable good, the production of the tradable good, and thus the tax revenue improve quickly. Consequently, employment and production in the government sector improves sooner in this case.

${ }^{29}$ This section discusses the activities of the intermediate goods firm only. The final goods firm is not discussed here as its role is not crucial to the economy. The final goods firm simply combines the output of the intermediate goods firm to produce a final good for the household. Under the alternative formulation of the model where there is no final goods firm and the household directly consumes both tradable and nontradable goods, the results of the model remain unchanged.

${ }^{30}$ When the collateral constraint is not binding, the shadow value is zero. Thus, prior to the crisis, at time zero, the shadow value of long-term debt is zero. 
resulting from another unit of long-term debt must be weighed against both these costs.

In reaction to the high shadow value of another unit of long-term debt, over time the firm reduces its level of long-term debt resulting in a lower steady-state value of debt (Figures A.1.5 and A.3.5). In turn, as the firm's profits are less dependent on long-term debt, the shadow value of another unit of long-term debt declines (Figures A.1.6 and A.3.6).

Initially, the liabilities side of the collateral constraint is also cut back by an immediate reduction in the use of the imported input in the production of the tradable good, thereby reining in short-term foreign debt. Liabilities are also reduced by an immediate reduction in labor used in the production of the nontradable good (which reduces short-term domestic debt) and subsequent decline of the nontradable good. The reduction of labor employed in the nontradable sector results in a decline in the marginal product of capital, resulting in a decline in the asset price of capital employed in the nontradable sector $\left(q^{N}\right)$, increasing the restrictiveness of the collateral constraint for the firm.

Tradable good production will initially decline but by less when there is some substitutability in production. In this case, more labor will be immediately allocated to the tradable good sector, substituting for the imported input. Due to the binding collateral constraint, the decrease in imported input will exceed the increase of domestic labor in the production of the tradable good. ${ }^{31}$ Consequently, despite an increase in labor, the production of the tradable good declines during the period the constraints become binding.

The increase in the domestic input, labor, used in the production of the tradable good increases the marginal product of capital, resulting in upward pressure on the asset price in the tradable sector. Meanwhile, the reduction in the imported input decreases the marginal product of capital. Since the decrease in the imported input exceeds the increase in labor, the marginal product of capital falls, resulting in a decline of the asset price of capital employed in the production of the tradable good $\left(q^{T}\right)$, further increasing the restrictions the collateral constraint places on the firm.

When there is less substitutability in production, the firm will initially employ less labor in conjunction with less imported input, production of the tradable good will initially decline. Under the assumption of perfect, or close to perfect, substitutability, domestic labor is just as

${ }^{31}$ Since the firm's goal is to meet the collateral constraint, the decrease in short-term foreign debt is greater than the increase in domestic debt for labor. That is, the decrease in the imported input is greater than the increase in labor. Technically,

$\Delta L w(1+r) \leq \Delta z\left(1+r^{*}\right)+\Delta B\left(1+r^{*}\right)$.

In other words, overall liabilities should fall. Although the wage rate $(w)$ initially declines, the domestic interest rate $(r)$ increases significantly in comparison to the world interest rate $\left(r^{*}\right)$, which remains constant. As a result, for most parameter assumptions, initially $w(1+r)$ increases while $\left(1+r^{*}\right)$ remains constant. Meanwhile, in the first period of the shock, the long-term debt from the previous period $(B)$ is not a choice variable for the current period, thus $\Delta B=0$. On the other hand, labor in the nontradable sector declines, reducing $\Delta L w(1+r)$. However, for most parameter assumptions, the increase in $w(1+r)$ is such that the increase in labor used in the tradable sector is less than the decrease in the imported input. 
efficient as the imported input in the production of the tradable good; however, output would still decline because the decline in the imported input will exceed the increase in labor employed in tradable good production.

In subsequent periods, the production of the tradable and nontradable goods will increase. As the level of long-term foreign debt declines, the firm is able to increase short-term foreign debt, increasing the use of the imported input (and replacing the less efficient input, labor) each period until steady-state is reached (Figure A.1.7). ${ }^{32}$ The less restrictive collateral constraint also permits the firm to increase short-term domestic debt for labor, improving employment (Figure A.1.10) and production (Figure A.1.11) in the nontradable good sector.

\section{Foreign Creditor in the Base Case}

In each period, the foreign creditor watches the government's shadow value of sovereign debt, where this value represents the premium the government is willing to pay for sovereign debt. ${ }^{33}$ When this premium is high, the foreign creditor is weary of the government's ability to maintain a specified level of production of the government good. ${ }^{34}$ Concerned about the economy's overall viability, the foreign creditor reduces the percentage of the firm's assets that are acceptable as collateral.

During the initial crisis phase, reacting to the government's high shadow value of sovereign debt, the foreign creditor accepts a lower percentage of a firm's assets as collateral. As the economy recovers, and the shadow value of sovereign debt declines (Figures A.1.4 and A.3.4), the foreign creditor gains confidence in the economy and increases the percentage of the firm's assets as acceptable collateral (Figures A.1.12 and A.3.12).

The firm, in turn, is able to borrow more, produce more, and provide increased tax revenue to the government. With greater tax revenue, the government is less desperate about its sovereign debt sustainability. The shadow value of sovereign debt declines faster. The foreign creditor reacts by accepting a higher percentage of assets as collateral contributing to the chain of reactions described above.

\section{Prices in the Base Case}

Exchange rate depreciation, represented by a higher price of the tradable good, initially acts to further the restrictions that the collateral and sovereign debt constraints place on the firm and the government. As the economy recovers, the exchange rate appreciates, reducing the value of firm and government foreign liabilities, easing the collateral and sovereign debt

\footnotetext{
${ }^{32}$ In the case of substitutability in production of the tradable good, the newly unemployed labor in the tradable sector is transferred to employment in the production of the nontradable good.

${ }^{33}$ In reality, this corresponds to sovereign debt premiums that large institutional investors are able to observe with almost no lag as have been assumed in the model.

${ }^{34}$ If the production of the government good suddenly falls below a particular level, its marginal utility to the household explodes, resulting in volatile interest rates, prices, and economic instability.
} 
constraints, and aiding the recovery process.

The price of the tradable good represents the units of domestic currency received from the sale of one unit of the tradable good, where the tradable good always sells for one unit of foreign currency. In equilibrium, market clearing for the tradable good determines the price of the tradable good (refer to equation 31 ).

Demand for the tradable good includes its domestic consumption, and gross foreign capital outflows, consisting of foreign debt and interest payments in terms of the tradable good by the firm and the government. ${ }^{35}$ The household initially consumes less and then as production and employment recover, so too does consumption (reduced household wealth reduces the demand for the final consumption good $(c)$, which in turn reduces the final goods firm's demand for the tradable and nontradable goods $\left.\left(c^{T}, c^{N}\right)\right)$. In the period that the constraints become binding, the dividend revenue of the household is healthy as it is from the previous, pre-crisis, period. However, the reduction in wealth resulting from unemployment outweigh the impact on wealth of dividends.

The initial fall in employment results in a reduction of wealth for the household. Lower income leads the household to spend less. Domestic demand for tradable and nontradable goods $\left(c^{T}, c^{N}\right)$ fall. As the economy recovers, the household's income increases and demand for tradable and nontradable goods increases (Figures A.1.14, A.1.15, A.3.14, and A.3.15). The initial fall in demand for nontradable goods (added to the fall in supply) further increases unemployment in this sector.

The supply of the tradable good consists of its domestic production and gross inflows of foreign capital in the form of new foreign debt taken on by the firm and the government.

Initially, the exchange rate depreciates significantly as a result of a large drop in supply of the tradable good relative to demand for the tradable good. The sudden drop in production of the tradable good reduces its supply significantly. ${ }^{36}$ The demand for the tradable good, however, falls less than supply because, despite an initial decline in consumption of the tradable good, capital outflows initially rise as the firm repays long-term foreign debt to meet the collateral constraint. ${ }^{37}$ In following periods, the exchange rate appreciates as a result of increased supply and demand of the tradable good, where the supply effect dominates (Figures A.1.16 and A.3.16). ${ }^{38}$ In particular, although demand for the tradable good increases as a result of increases in consumption of the tradable good, capital outflows are generally declining, mitigating the increases in demand from increased consumption of the tradable

${ }^{35}$ Exports of the tradable good are defined as sales of the tradable good for the purpose of repaying interest and principal on foreign debt, both short and long-term.

${ }^{36}$ The supply falls despite an initially large level of gross capital inflows (especially in the form of foreign long-term debt). In the following periods, as firms and the government reduce their foreign long-term debt, the level of capital inflows declines.

${ }^{37}$ When there is substitutability in production of the tradable good then this difference is smaller and the exchange rate depreciates by less.

${ }^{38}$ The effect of the increase in production outweighs the reduction in gross capital inflows. 
good.

The price level (a weighted average of the prices of tradable and nontradable goods) and the real exchange rate (represented by the price of the tradable good relative to the price of the nontradable good), being functions of the nominal exchange rate, follow the same pattern as the nominal exchange rate. ${ }^{39,40}$

Interest rates in this economy are determined by the demand and supply of loanable funds. Although both the supply and demand for loanable funds initially decline, the decrease in supply (resulting from a large reduction in household income and hence savings) dominates. The result is an initially high interest rate that declines over time as supply of loanable funds increases relative to demand (Figures A.1.19 and A.3.19).

\section{B. Application of Disciplined Fiscal Policy}

The application of disciplined fiscal policy has contrasting effects on the economy depending on the flexibility in production of the economy. When the economy has more flexibility in production, disciplined fiscal policy improves the overall performance of the economy. The severity of the crisis, in terms of depth and length, is significantly reduced. Disciplined fiscal policy has the opposite impact on the economy with less flexibility in production. The severity of the crisis worsens in terms of both depth and length.

\section{Flexibility in Production of Tradable Goods under Disciplined Fiscal Policy}

All variables initially react in the same direction as in the base case; however, the magnitudes of their reactions are different. In the period when crisis strikes, creating a 3 percent surplus is costly for the government. The sovereign debt constraint becomes more restrictive than in the base case. The shadow value of sovereign debt rises above that in the base case. Initially, the government reacts by increasing tax rates by more than in the base case in order to create a surplus; employment and production of the government good are less than in the base case.

In each of the following periods the surplus created in the previous period reduces the strain on the government to meet the sovereign debt constraint. The shadow value of sovereign debt declines quickly and is less than in the base case (Figure A.2.4). With less pressure on taxes, as a result of the surplus carried over from the previous period, the tax rate also gradually declines below the base case tax rate (Figure A.2.1). Employment and production in the government sector conversely increase relative to the base case (Figures A.2.2 and A.2.3). ${ }^{41}$

\footnotetext{
${ }^{39}$ The price of the nontradable good will increase or decrease depending on whether the supply or demand effect is larger. In the simulations shown here, the supply effect is larger and so initially the price of the nontradable good increases. As the economy recovers, the price of the nontradable good returns to its lower steady-state level.

${ }^{40}$ When there is less flexibility in production, the production of the tradable good declines much more, resulting in a larger depreciation of the exchange rate (than in the economy with more flexibility in production). Consequently, the real exchange rate depreciates more and prices rise more than when there is less flexibility in production.

${ }^{41}$ In the simulations presented, the government earns interest on the surplus it carries over to
} 
The foreign creditor reacts to the initially large shadow value of sovereign debt by reducing the percentage of a firm's assets accepted as collateral, relative to the base case.

Consequently, the firm's collateral constraint becomes more restrictive. The firm adjusts by employing relatively less of the imported input in tradable good production. It uses less labor in nontradable good production than in the base case but relatively more labor in tradable production. Consequently, production of the nontradable good is initially lower than in the base case and production of the tradable good is only slightly lower than in the base case. The higher shadow value of long-term debt leads to a relatively lower level of new long-term debt undertaken in the initial period.

In following periods, responding to a lower shadow value of sovereign debt, the foreign creditor accepts a higher percentage of the firm's assets as collateral. The collateral constraint is less restrictive for the firm, relative to the base case. Consequently, the firm employs more imported input in the production of the tradable good (Figure A.2.7). The firm, therefore, depends less on the substitutability of domestic labor for imported inputs. The employment of labor in the tradable sector is less than in the base case (Figure A.2.8). Overall, production of the tradable good increases as a result of the firm being able to employ more of the imported input (Figure A.2.9).

The less restrictive collateral constraint also enables the firm to hire more labor in the nontradable sector (Figure A.2.10), and raise its production (Figure A.2.11). With higher levels of employment in the economy as a whole, household income increases, contributing to higher consumption (Figures A.2.14 and A.2.15). ${ }^{42}$

The exchange rate depreciates less than in the base case (Figure A.2.16), thereby reducing the restrictiveness of the collateral and sovereign debt constraints on the firm and the government. The supply as well as the demand for the tradable good both decreases less than in the base case. However, as in the base case, the reduction in supply is still greater than in demand. Consequently, the exchange rate still depreciates but by less. The real exchange rate (Figure A.2.17) and the price level (Figure A.2.18) follow a similar pattern.

\section{Less Flexibility in Production of Tradable Goods under Disciplined Fiscal Policy}

When there is less flexibility in the production of the tradable good, the application of disciplined fiscal policy worsens the severity of the crisis. The initial reaction of this economy is qualitatively similar to the economy maintaining a sustained 3 percent surplus

the following period at the risk-free world rate of interest. A portion of the interest income is used to fund labor expenses. The other portion is used to meet the surplus requirements, which are growing in value as the output of the country grows (since the surplus requirement is 3 percent of output). When there is no interest earned on the surplus, the model results are qualitatively the same; however, quantitatively the recovery process is a bit slower since the previous period's surplus is less effective in helping to loosen the sovereign debt constraint. This results in higher shadow values of sovereign debt, tax rates, and comparatively lower levels of employment and production in the government sector.

${ }^{42}$ Relative to the base case, the increase in demand for labor exceeds the increase in supply, resulting in higher wages. 
with more flexibility in production. However, because the firm is unable to substitute domestic labor for the imported input, the production of the tradable good declines much more.

To sustain a 3 percent budget surplus, the government reacts by increasing the tax rate (relative to the base case) more than under production flexibility. Despite the large increase in the tax rate, the lower production of the tradable good reduces the overall tax revenue by more than in the economy with greater flexibility. As a result, the government cuts back employment and reduces the output of the government good further (relative to the base case). The shadow value of sovereign debt (relative to the base case) goes up more than in the flexible economy.

In each subsequent period, the policy to maintain a budget surplus in the midst of a slow recovery of the tradable good puts a heavy burden on the government. On the one hand, the surplus created in the previous period gradually reduces that burden for meeting the sovereign debt constraint. The pressure to raise taxes is gradually relieved. On the other hand, the low tradable good production forces the government to maintain a higher tax rate than in the base case (Figure A.4.1). Employment and production in the government sector are also reduced relative to the base case so that the budget surplus can be maintained (Figures A.4.2 and A.4.3). ${ }^{43}$ In contrast to the economy with more flexible production, the shadow value of sovereign debt declines gradually but remains higher than in the base case (Figure A.4.4).

The initial high shadow value of sovereign debt results in the foreign creditor reducing the percentage of firm's assets accepted as collateral (relative to the base case). Compared to the economy with more flexibility, the firm's collateral constraint is initially more restrictive contributing to a larger reduction of the imported input use and a reduction of labor and production in the nontradable sector. Because the firm is unable to substitute domestic labor for imported input, employment of labor and production decline in the tradable sector as well. The higher shadow value of long-term debt leads to a relatively lower level of new long-term debt undertaken in the initial period.

Reacting to a gradually declining shadow value of sovereign debt, the foreign creditor very gradually accepts a higher percentage of the firm's assets as collateral (Figure A.4.12). Relative to the base case, the collateral constraint in any given period is more restrictive for the firm. Over time, however, the collateral constraint becomes less constraining; the shadow value of long-term foreign debt declines (Figure A.4.6). Consequently, the firm employs more imported input in the production of the tradable good (Figure A.4.7). Therefore, the firm is less dependent on the substitutability of domestic labor for imported inputs. The employment of labor in the tradable sector is less than in the base case (Figure A.4.8). Overall, production of the tradable good increases as a result of the firm being able to employ

${ }^{43}$ In the simulations presented, the government earns interest on the surplus it carries over to the following period at the risk-free world rate of interest. In the economy with less flexibility in production, the major portion of the interest is used to meet the surplus requirements that are growing in value as the output of the country grows (since the surplus requirement is 3 percent of output). A small remaining portion of the interest income is used to fund labor expenses. 
more of the imported input (Figure A.4.9), but remains less than in the base case.

Although the collateral constraint becomes less restrictive over time relative to the base case, the firm hires less labor in the nontradable sector (Figure A.4.10). The production of the nontradable good, lower in the beginning (Figure A.4.11), improves over time. Employment in the economy is less than in the base case, as is household income. Consequently, consumption levels are lower than in the base case (Figures A.4.14 and A.4.15). ${ }^{44}$

The exchange rate depreciates more than in the base case (Figure A.4.16). The supply and demand for the tradable good both decrease more than in the base case. However, as in the base case, the reduction in supply is still greater than in demand. Consequently, the exchange rate depreciates by much more. The real exchange rate (Figure A.4.17) and the price level (Figure A.4.18) again follow a similar pattern.

\section{Application of Simulation Results to Korea and Thailand}

Emerging market economies exporting intermediate or final goods that require imported inputs in production (supported by foreign credit) are susceptible to sudden exchange rate depreciations. During a financial crisis, the exporting firms undergoing severe damage to their balance sheets are the very firms that can lead the recovery process through increased export sales as a result of the depreciated exchange rate. Korea (from early 1998) and Thailand (from mid-1997) are examples of such economies.

Korea and Thailand, after 1997-98, had contrasting recovery paths. Korea's remarkably strong export-led recovery path combined firms that were able to continue production during the crisis and rapidly attract capital inflows. Korea fits the model's feature of flexible production, which induces the return of foreign capital inflows. In Figure 9, foreign capital inflows returned to Korea in the middle of fiscal discipline.

Figure 9. Korea (1996-2000)

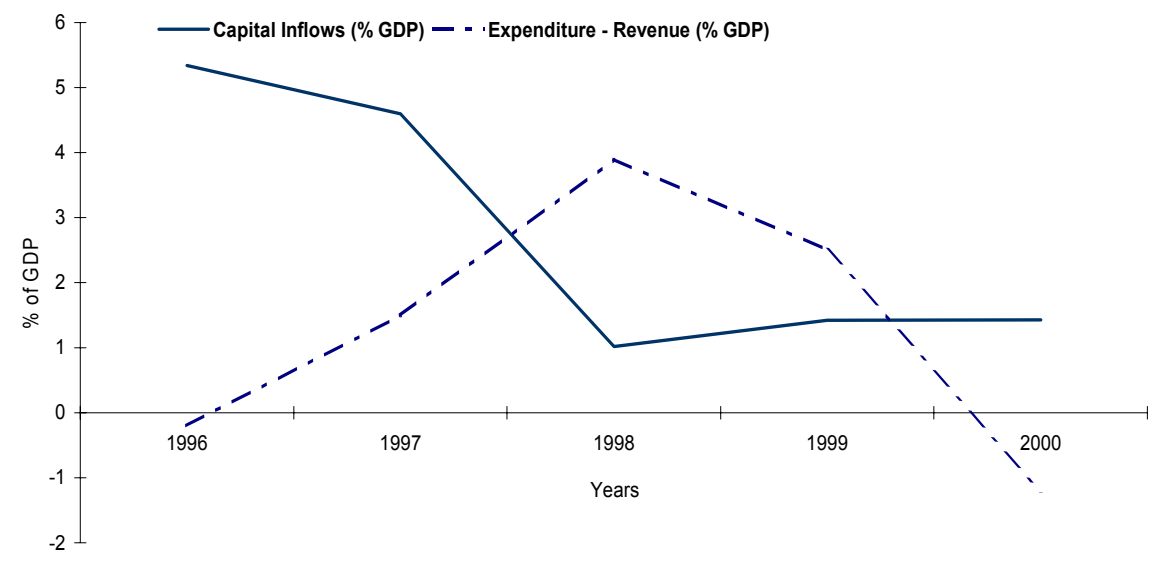

Source: Economic Intelligence Unit.

${ }^{44}$ Relative to the base case, the increase in demand for labor is less than the increase in supply, resulting in lower wages. 
By contrast, post-1997 Thailand had a slower export-led recovery. With less production flexibility, Thai firms suffered as a result of disciplined fiscal policy. In Figure 10, despite Thailand's efforts to contain its budget deficit, capital flows initially continued to exit and were sluggish to return.

Figure 10. Thailand (1996-2001)

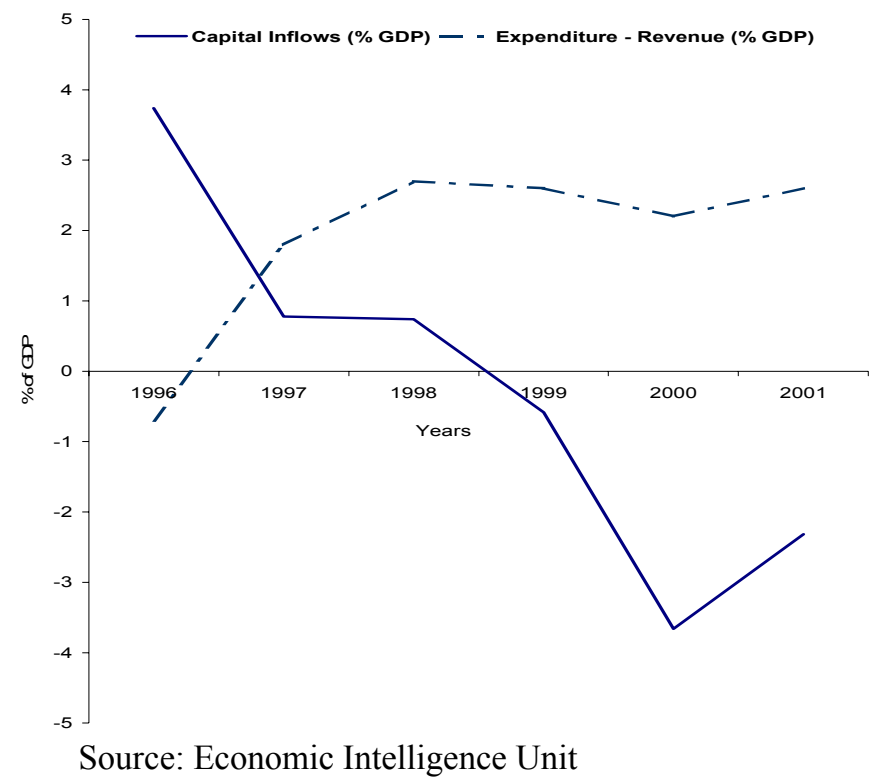

\section{CONCLUSIONS AND FURTHER RESEARCH}

The IMF recommendation of disciplined fiscal policy to emerging markets in crisis, relative to the findings of this paper, is appropriate for some countries and not for others. The model demonstrates that disciplined fiscal policy can result in starkly contrasting recovery paths across emerging market economies. The consequences of disciplined fiscal policy depends on the underlying structure of the economy. Economies where exporting firms can continue production despite the crisis, lead the recovery process. Disciplined fiscal policy, through its signaling impact on the foreign creditor, supports the recovery process by enhancing the production capabilities of exporting firms. By contrast, in economies where exporting firms face significant difficulties in continuing production during a crisis, fiscal discipline associated with low tax revenue serves as a negative signal to foreign creditors and impedes the recovery process.

While this model provides important qualitative results relating the impact of disciplined fiscal policy on post-crisis recovery, it lacks quantitative measures of the extent to which fiscal tightening can help or hinder the recovery process. In future research, I hope to provide measures of the relationship between production flexibility and fiscal policy requirements that can enhance or worsen post-crisis recovery.

Finally, policy recommendations during recent emerging market crises involved both fiscal and monetary policy. This paper has focused on the implications of fiscal policy alone. My undergoing research extends the framework developed in this paper to study the dynamics between fiscal and monetary policy in crisis-stricken emerging market economies. 


\section{References}

Aghion, P., P. Bacchetta, and A. Banerjee, 2001, "Currency Crises and Monetary Policy in an Economy with Credit Constraints," European Economic Review, Vol. 45, No. 7, pp. 1121-50.

Alesina, A., and R. Perotti, 1995, "Fiscal Expansion and Fiscal Adjustments in OECD Countries," Economic Policy, A European Forum, Vol. 21, pp. 205-48.

Arellano, C., and E.G. Mendoza, 2002, "Credit Frictions and 'Sudden Stops' in Small Open Economies: An Equilibrium Business Cycle Framework for Emerging Market Crises," NBER Working Paper 8880 (Cambridge, Massachusetts: National Bureau of Economic Research).

Boorman, J., T. Lane, M. Schulze-Ghattas, A. Bulir, A.R. Ghosh, J. Hamann, A. Mourmouras, and S. Phillips, 2000, "Managing Financial Crises: The Experience in East Asia," IMF Working Paper 00/107 (Washington: International Monetary Fund).

Boughton, J.M., 2001, "Different Strokes? Common and Uncommon Responses to Financial Crises," IMF Working Paper 01/12 (Washington: International Monetary Fund).

Bulow, J., and K. Rogoff, 1989, “A Constant Recontracting Model of Sovereign Debt," Journal of Political Economy, Vol. 97, No.1, pp. 155-78.

Caballero, R., and A. Krishnamurthy, 2001, "International and Domestic Collateral Constraints in a Model of Emerging Market Crises," Journal of Monetary Economics, Vol. 48, pp. 513-48.

__, 2004, "Fiscal Policy and Financial Depth," NBER Working Paper 10532 (Cambridge, Massachusetts: National Bureau of Economic Research).

Calvo, G. A., 1998, "Capital Flows and Capital-Market Crises: The Simple Economics of Sudden Stops," Journal of Applied Economics, Vol. 1, pp. 33-54.

— , and C. Reinhart, 2000, "When Capital Inflows Come to a Sudden Stop: Consequences and Policy Options," in Key Issues in Reform of the International Monetary and Financial System, ed. by P. Kenen and A. Swoboda (Washington: International Monetary Fund), pp. 175-201.

Cespedes, L.F., R. Chang, and A. Velasco, 2000, "Balance Sheets and Exchange Rate Policy,” NBER Working Paper 7840 (Cambridge, Massachusetts: National Bureau of Economic Research).

Chari, V.V., and P. Kehoe, 2003, "Financial Crises as Herds: Overturning the Critiques," NBER Working Paper 9658 (Cambridge, Massachusetts: National Bureau of Economic Research). 
Chopra, A., K. Kang, M. Karasulu, H. Liang, H. Ma, and A. Richards, 2001, "From Crisis to Recovery in Korea: Strategy, Achievements, and Lessons," IMF Working Paper 01/154 (Washington: International Monetary Fund).

Christiano, L.J., C. Gust, and J. Roldos, 2004, "Monetary Policy in a Financial Crisis," Journal of Economic Theory, Vol. 119 No.1, pp. 64-103.

Corsetti, G., P. Pesenti, and N. Roubini, 2001, "The Role of Large Players in Currency Crises," NBER Working Paper 8303 (Cambridge, Massachusetts: National Bureau of Economic Research).

Desai, P., 2000, "Why Did the Ruble Collapse in August 1998?" American Economic Review, Vol. 90, No. 2, pp. 48-52.

—_, 2003a, Financial Crises, Contagion, and Containment: From Asia to Argentina (Princeton: Princeton University Press).

— , 2003b, "Explorations in Light of Financial Turbulence from Asia to Argentina," presented in Conference on the Future of Globalization: Explorations in Light of Recent Turbulence, Yale Center for the Study of Globalization, Yale University, October 10-11.

—_, and P. Mitra, 2004, "Why Do Some Countries Recover More Readily from Financial Crises?" presented in Festchrift in Honor of Guillermo Calvo (Washington: International Monetary Fund, April 15-16).

Eaton, J., and M. Gersovitz, 1981, "Debt with Potential Repudiation: Theoretical and Empirical Analysis," Review of Economic Studies, Vol. 48, No. 2, pp. 289-309.

The Economist, 2004, “Argentina: A Serious Country?” June 5-11, Vol. 371 No. 8378.

Furman, J., and J.E. Stiglitz, 1998, "Economic Crises: Evidence and Insights from East Asia," Brookings Papers on Economic Activity, Vol. 2, pp. 1-114 (Washington: Brookings Institution).

Giavazzi, F., and M. Pagano, 1990, “Can Severe Fiscal Contractions Be Expansionary?” NBER Macroeconomics Annual, ed. by O.Blanchard and S. Fischer (Cambridge, Massachusetts: National Bureau of Economic Research).

— 1996 , "Non-Keynesian Effects of Fiscal Policy Changes: International Evidence and the Swedish Experience,” NBER Reprints 2082 (Cambridge, Massachusetts: National Bureau of Economic Research).

Hemming, R., M. Kell, and S. Mahfouz, 2002, “The Effectiveness of Fiscal Policy in Stimulating Economic Activity-A Review of the Literature," IMF Working Paper 02/208 (Washington: International Monetary Fund).

International Monetary Fund, 2003, "The IMF and Recent Capital Account Crises: Indonesia, Korea, Brazil," Independent Evaluation Report (Washington). 
Kaminsky, G.L., and C. Reinhart, 2000, “On Crises, Contagion, and Confusion,” Journal of International Economics, Vol. 51, pp. 145-68.

Kehoe, P., and F. Perri, 2000, "International Business Cycles with Endogenous Incomplete Markets," NBER Working Paper 7870 (Cambridge, Massachusetts: National Bureau of Economic Research).

Kopits, G., 2000, “How Can Fiscal Policy Help Avert Crises?” IMF Working Paper 00/185 (Washington: International Monetary Fund).

Krugman, P., 1999, The Return of Depression Economics (New York: W.W. Norton \& Company).

Park, Y.C., and, J. Lee, 2001, “Recovery and Sustainability in East Asia,” NBER Working Paper 8373 (Cambridge, Massachusetts: National Bureau of Economic Research).

Mendoza, E.G., 2002, "Credit, Prices, and Crashes: Business Cycles with a Sudden Stop,” in Preventing Currency Crises in Emerging Markets, ed. by J. Frankel and S. Edwards (Chicago: University of Chicago Press).

Milesi-Ferreti, G.M., and A. Razin, 2000, "Current Account Reversals and Currency Crises: Empirical Regularities," in Currency Crises, ed. by P. Krugman (Chicago: University of Chicago Press).

Obstfeld, M., and K. Rogoff, 1996, Foundations of International Macroeconomics (Cambridge: MIT Press).

Rebelo, S., and C. Vegh, 1995, "Real Effects of Exchange-Rate-Based Stabilization: An Analysis of Competing Theories," NBER Macroeconomics Annual, pp. 125-87 (Cambridge, Massachusetts: National Bureau of Economic Research).

Sachs, J.D., 1998, "The IMF and the Asian Flu," The American Prospect, Vol. 37, pp.16-21.

Uribe, M., 1997, "Exchange-Rate-Based Inflation Stabilization: The Initial Real Effects of Credible Plans," Journal of Monetary Economics, Vol. 39, No. 2, pp. 197-221. 
Appendix: Simulated Paths of Variables

Figure A.1. Base Case, Flexibility in Production
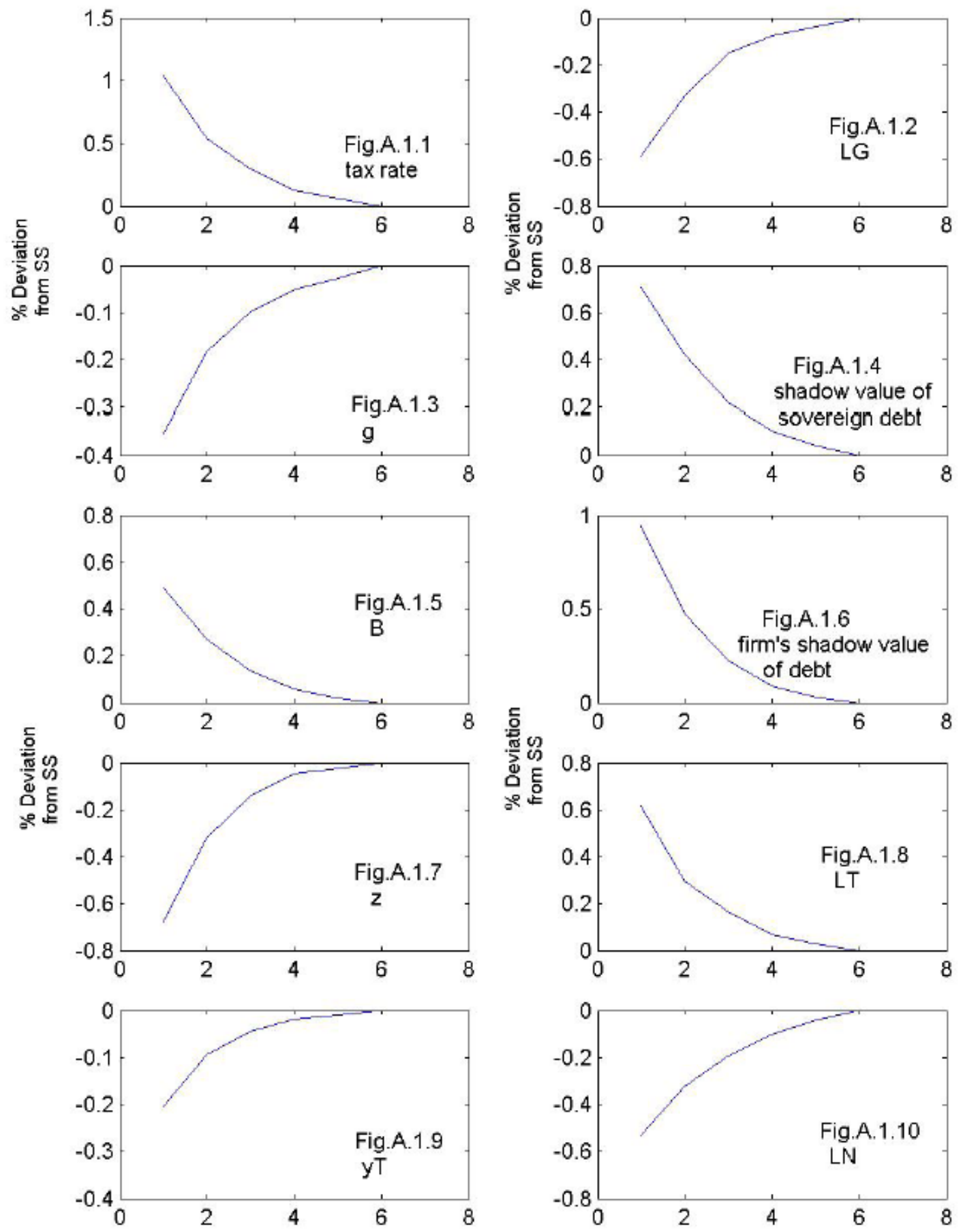

1. Financial crises strikes in period 1 when the government's and firm's debt constraints (defined in the text) become binding. 2. Periods 2 to 8 are post-crisis recovery periods. 3.The final steady-state is reached by period 7 in the base case simulation. 4. All variables are charted as percentage deviations from their steady values. 5. The base case represents a post-crisis path of variables where the government sustains a 0 percent budget surplus. 
Figure A.1 (Cont'd). Base Case, Flexibility in Production
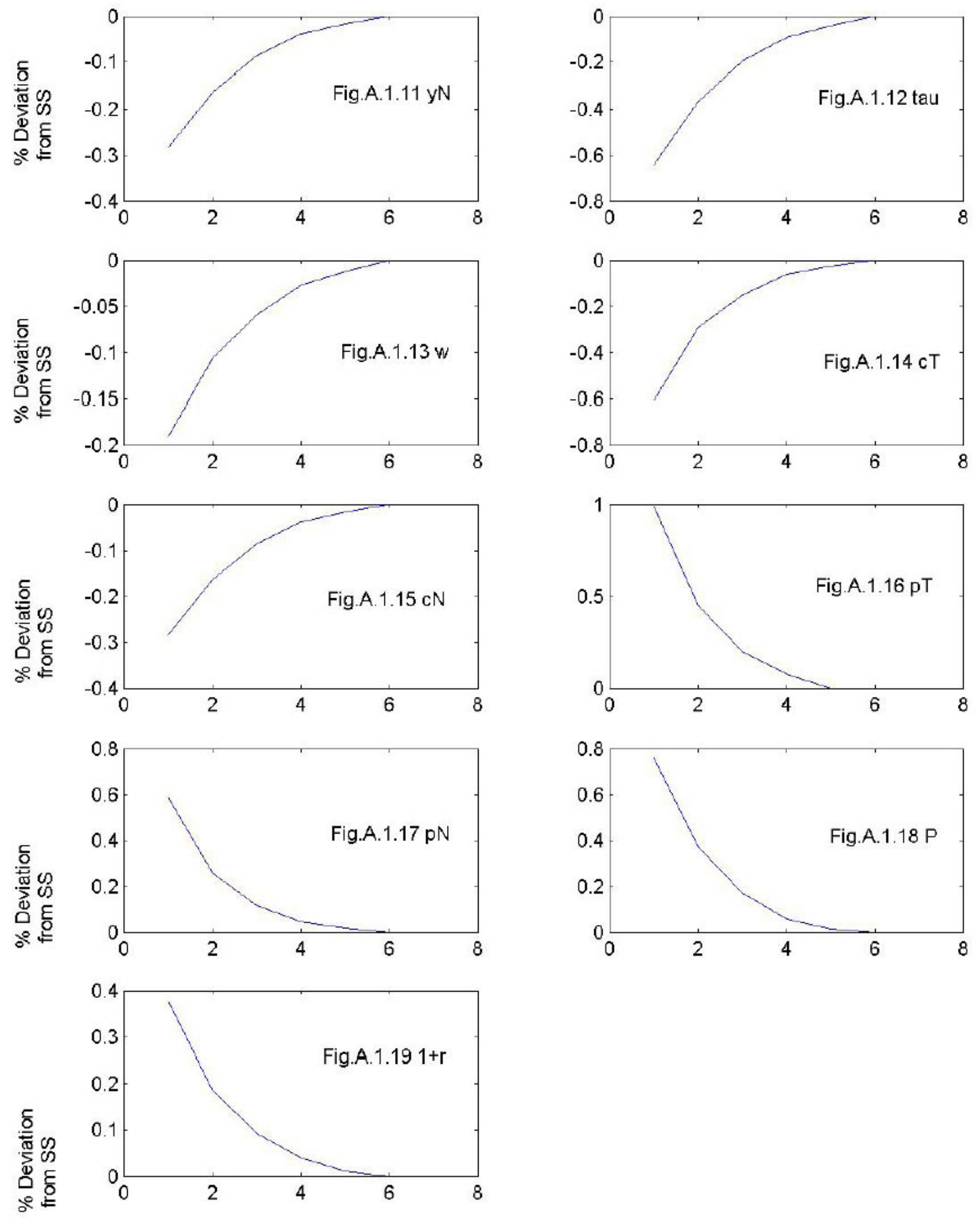

1. Financial crises strikes in period 1 when the government's and firm's debt constraints (defined in the text) become binding. 2. Periods 2 to 8 are post-crisis recovery periods. 3.The final steady-state is reached by period 7 in the base case simulation. 4 . All variables are charted as percentage deviations from their steady values. 5 . The base case represents a postcrisis path of variables where the government sustains a 0 percent budget surplus. 
Figure A.2. Three Percent Budget Surplus, Flexibility in Production
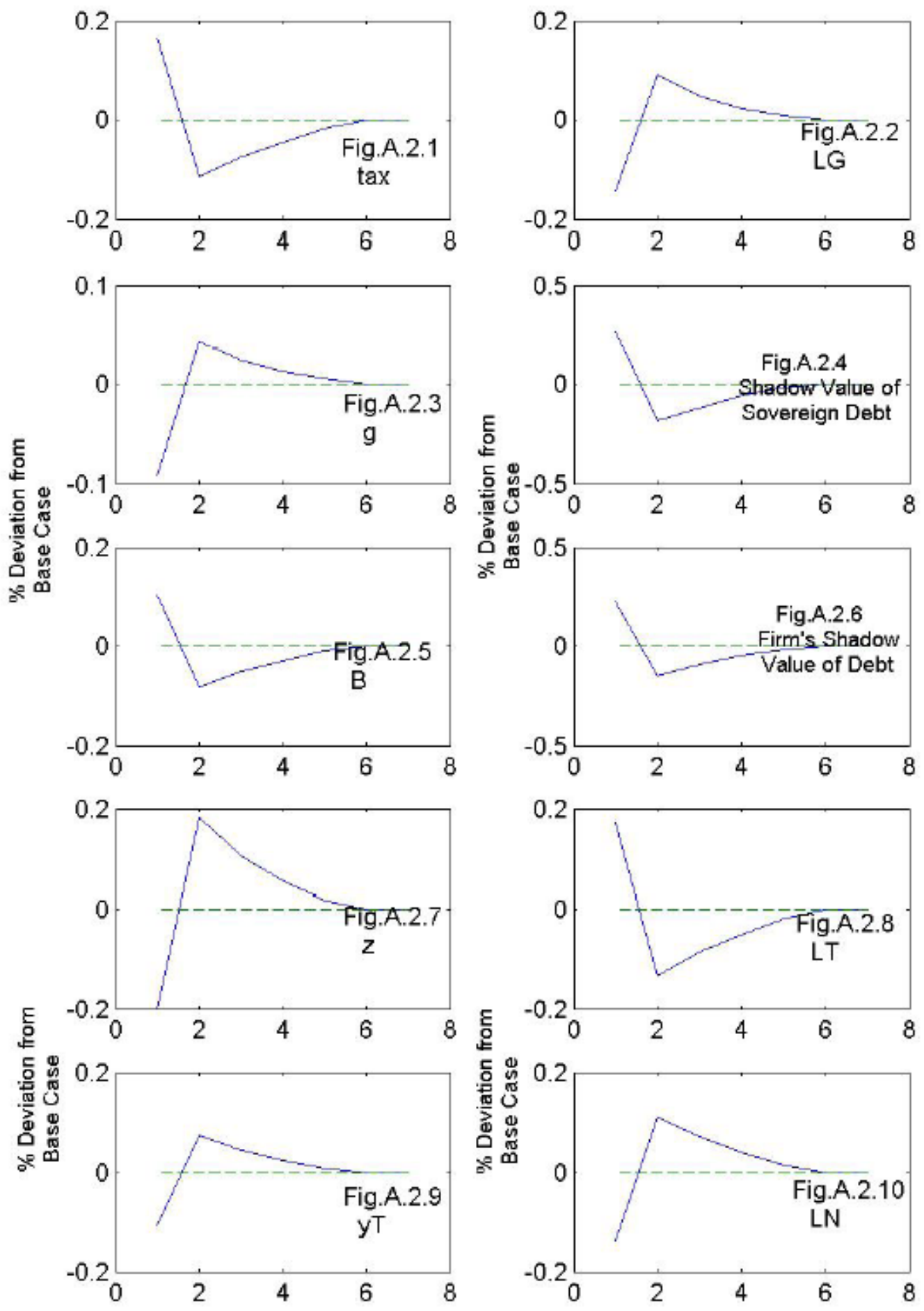

1. Financial crises strikes in period 1 when the government's and firm's debt constraints (defined in the text) become binding. 2. Periods 2 to 8 are post-crisis recovery periods. 3.The final steady-state is reached by period 7 in the base case simulation. 4 . All variables are charted as percentage deviations from their steady values. 5 . The base case represents a postcrisis path of variables where the government sustains a 0 percent budget surplus. 
Figure A.2 (Cont'd). Three Percent Budget Surplus, Flexibility in Production
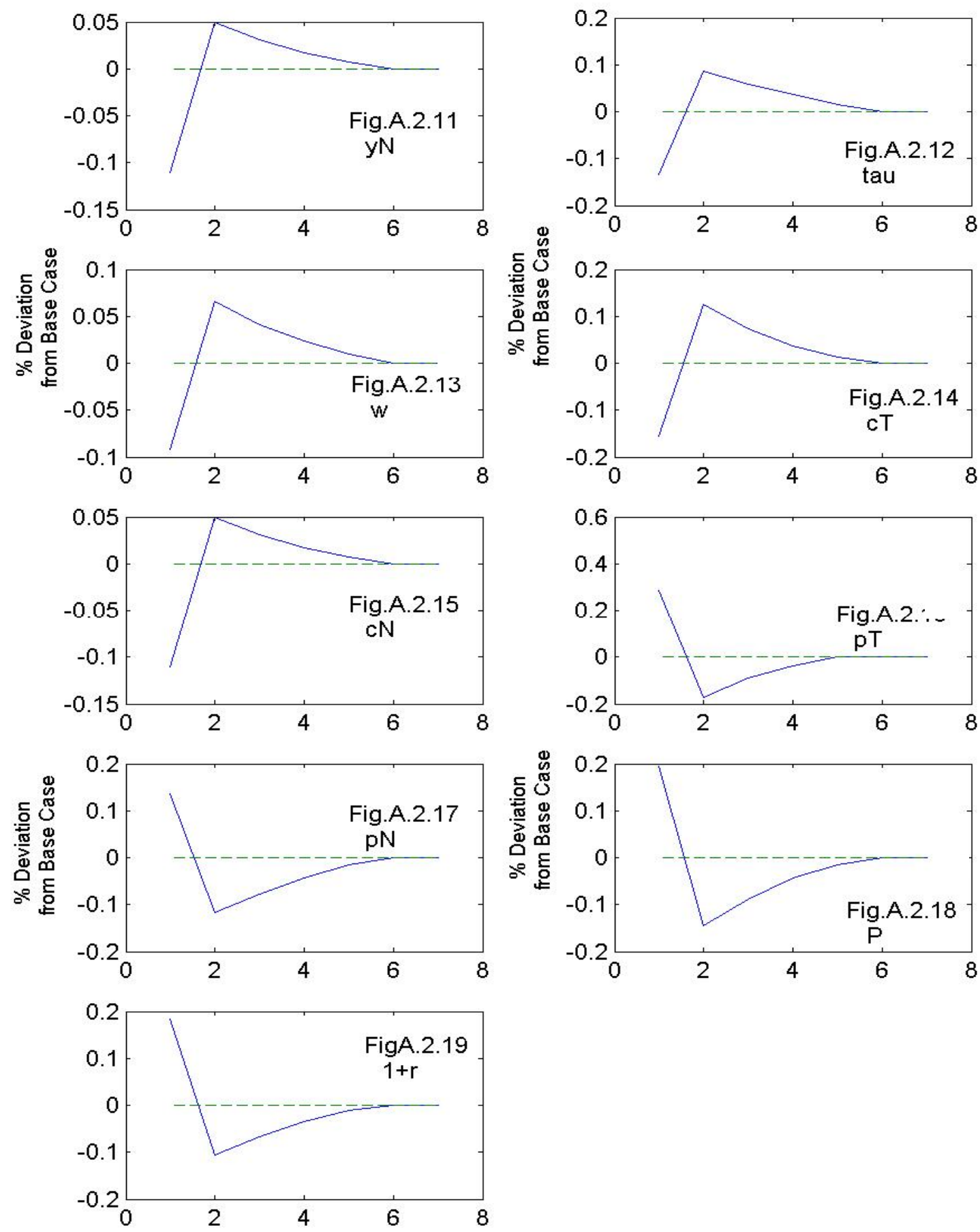

1. Financial crises strikes in period 1 when the government's and firm's debt constraints (defined in the text) become binding. 2. Periods 2 to 8 are post-crisis recovery periods. 3.The final steady-state is reached by period 7 in the base case simulation. 4 . All variables are charted as percentage deviations from their steady values. 5 . The base case represents a postcrisis path of variables where the government sustains a 0 percent budget surplus. 
Figure A.3. Base Case, Less Flexibility in Production
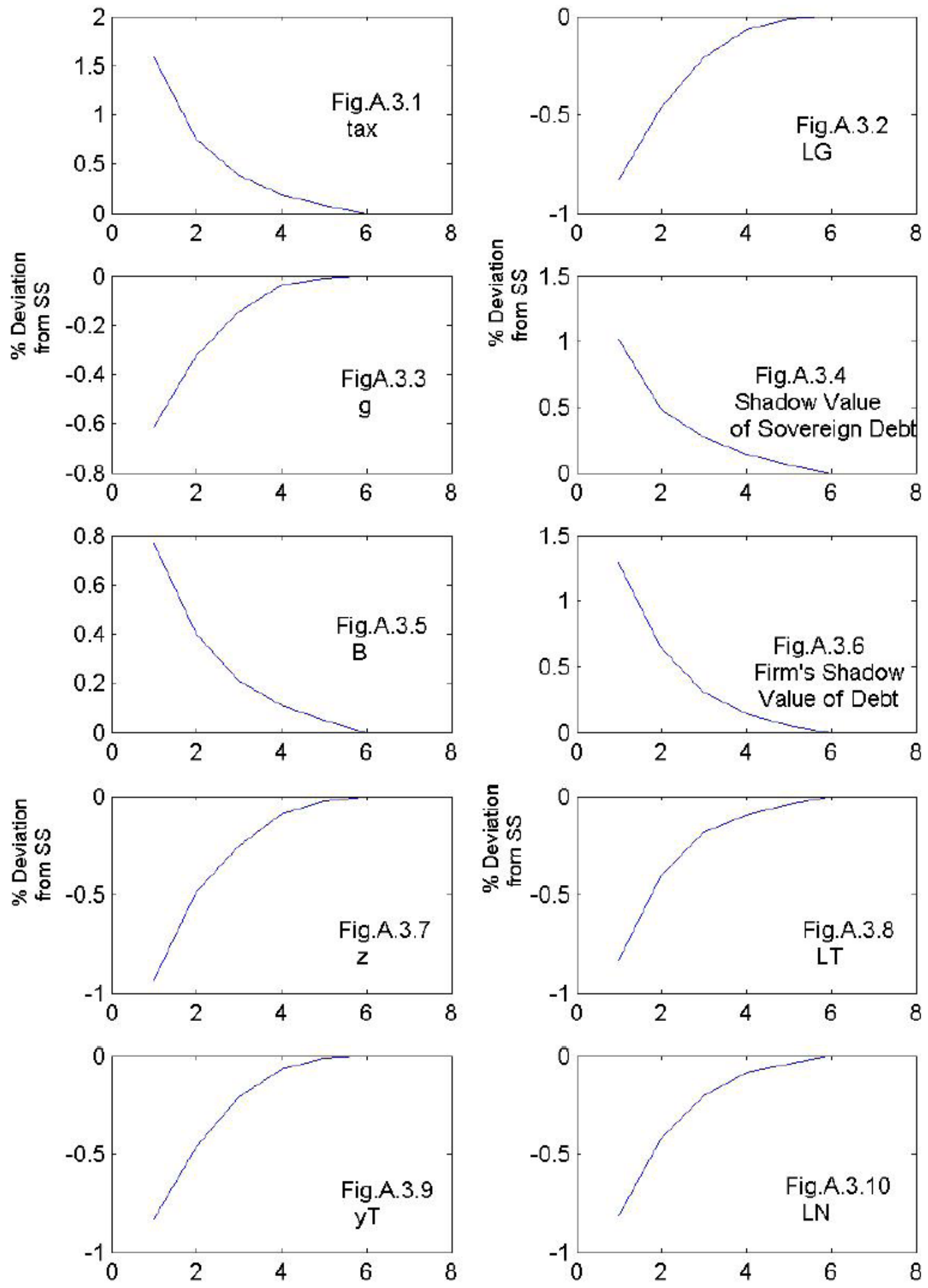

1. Financial crises strikes in period 1 when the government's and firm's debt constraints (defined in the text) become binding. 2. Periods 2 to 8 are post-crisis recovery periods. 3.The final steady-state is reached by period 7 in the base case simulation. 4 . All variables are charted as percentage deviations from their steady values. 5 . The base case represents a postcrisis path of variables where the government sustains a 0 percent budget surplus. 
Figure A.3 (Cont'd). Base Case, Less Flexibility in Production
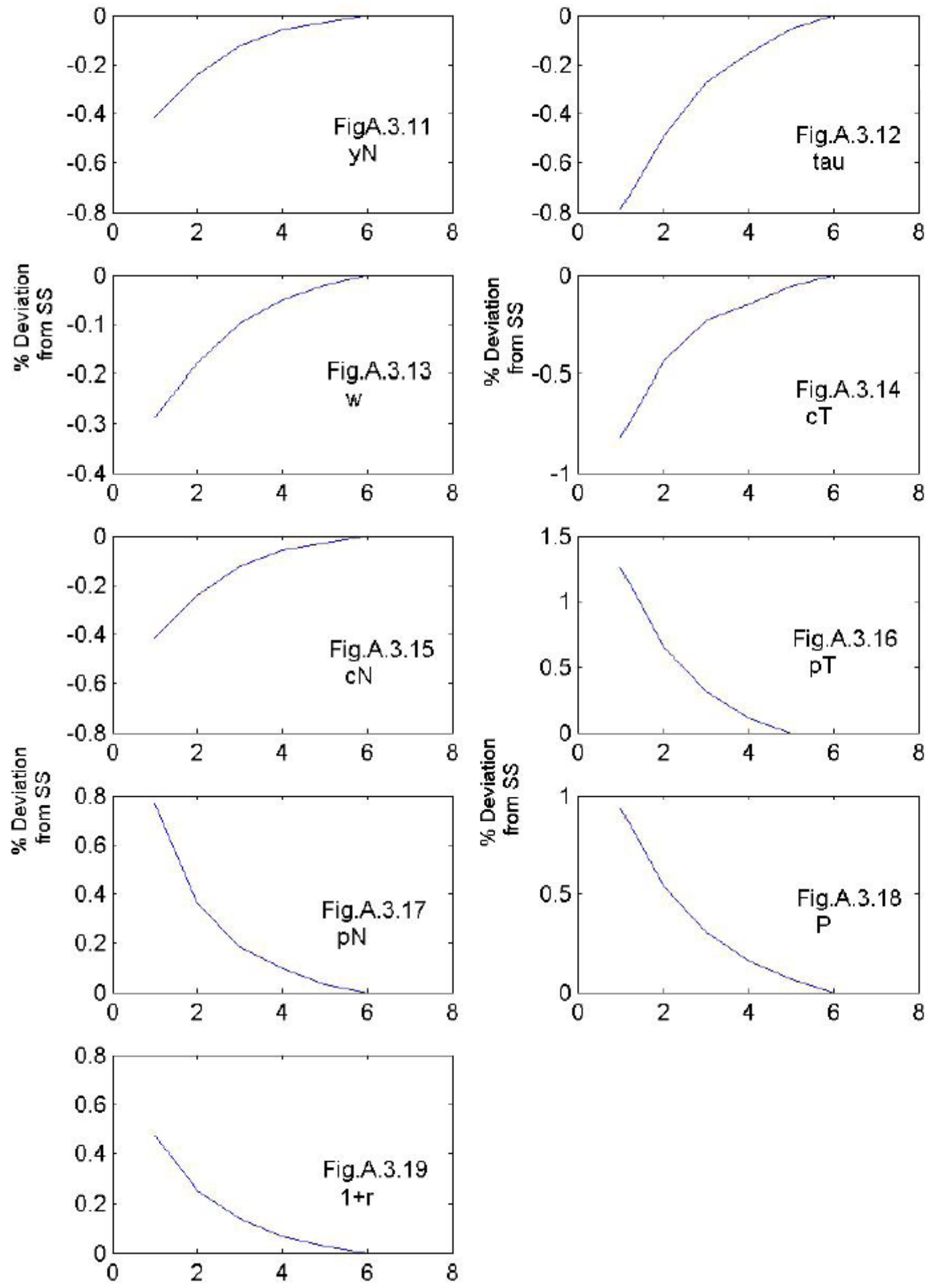

1. Financial crises strikes in period 1 when the government's and firm's debt constraints (defined in the text) become binding. 2. Periods 2 to 8 are post-crisis recovery periods. 3.The final steady-state is reached by period 7 in the base case simulation. 4 . All variables are charted as percentage deviations from their steady values. 5 . The base case represents a postcrisis path of variables where the government sustains a 0 percent budget surplus. 
Figure A.4. Three Percent Budget Surplus, Less Flexibility in Production
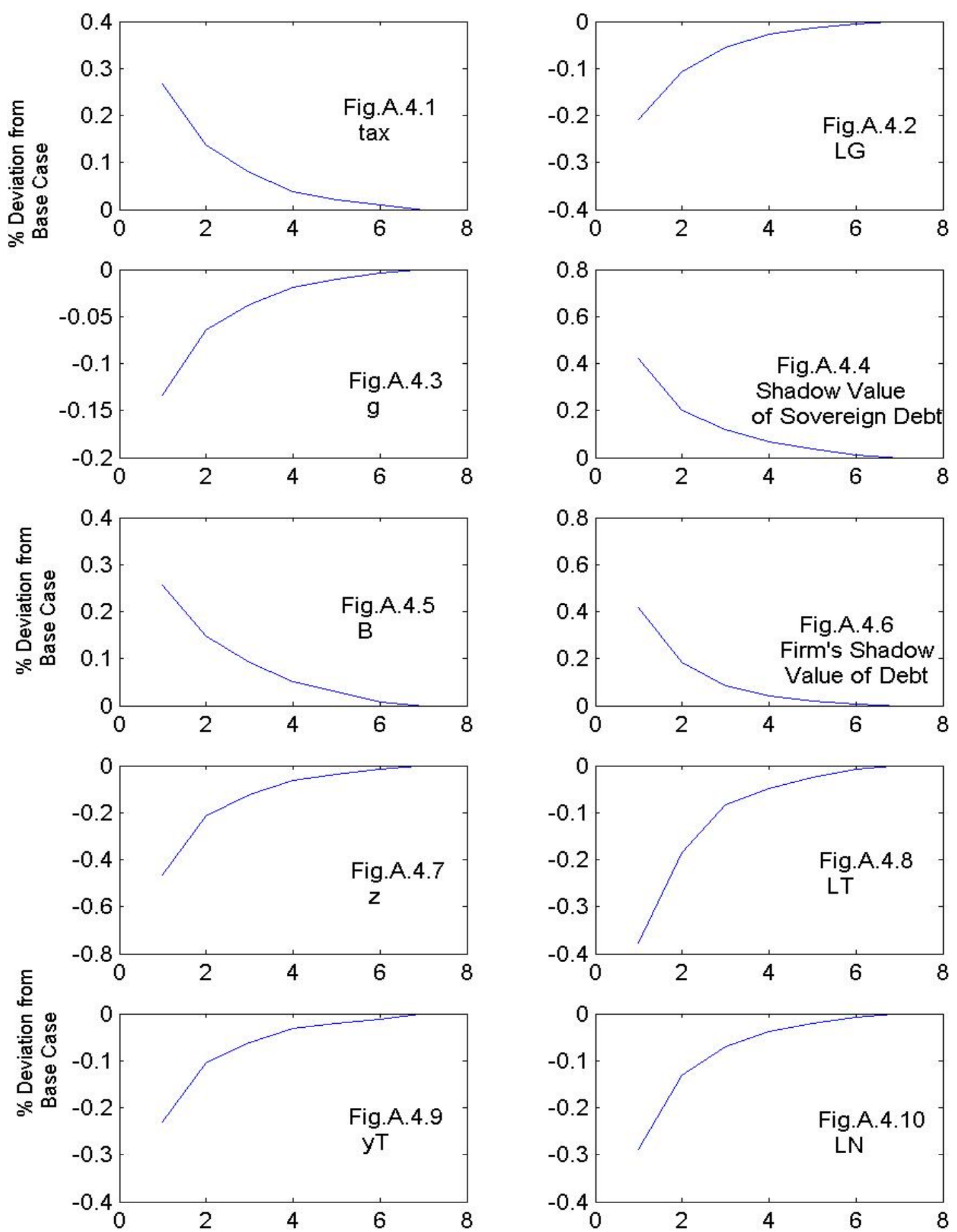

1. Financial crises strikes in period 1 when the government's and firm's debt constraints (defined in the text) become binding. 2. Periods 2 to 8 are post-crisis recovery periods. 3.The final steady-state is reached by period 7 in the base case simulation. 4 . All variables are charted as percentage deviations from their steady values. 5 . The base case represents a postcrisis path of variables where the government sustains a 0 percent budget surplus. 
Figure A.4 (Cont'd). Three Percent Budget Surplus, Less Flexibility in Production
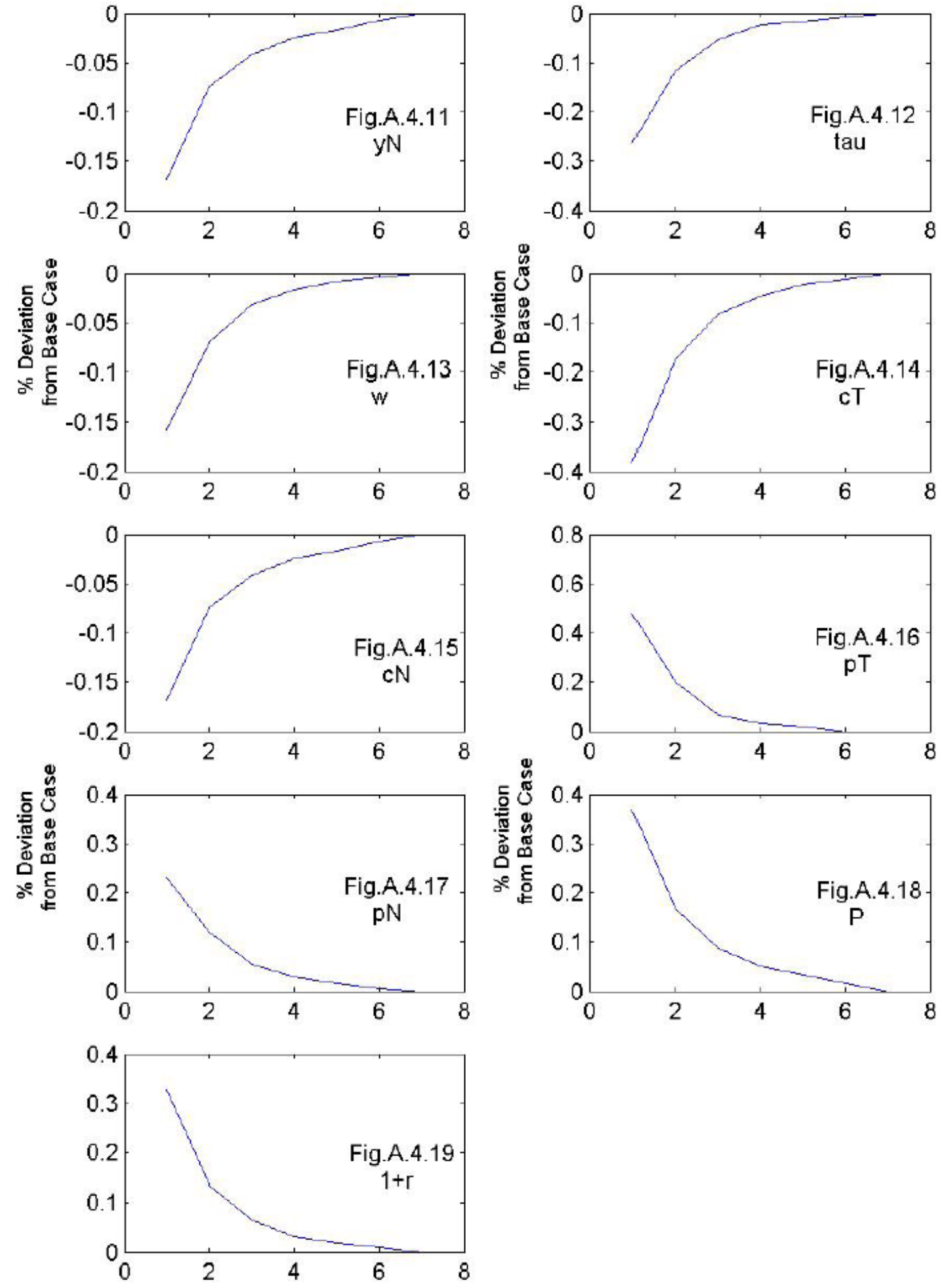

1. Financial crises strikes in period 1 when the government's and firm's debt constraints (defined in the text) become binding. 2. Periods 2 to 8 are post-crisis recovery periods. 3.The final steady-state is reached by period 7 in the base case simulation. 4 . All variables are charted as percentage deviations from their steady values. 5 . The base case represents a postcrisis path of variables where the government sustains a 0 percent budget surplus. 